\title{
As Eleições de 1899 a 1901 no Porto: a votação no Partido \\ Republicano Português — dos deputados da peste à ignóbil porcaria
}

\author{
José Pedro Oliveira Pinto \\ josepedroliveirapinto@gmail.com
}

\section{Resumo}

O presente artigo foca-se nas eleições para a Câmara dos Deputados de 1899 a 1901 no Porto, considerando particularmente os resultados do Partido Republicano Português (PRP), tendo como objectivo compreender os impactos das leis eleitorais e a conjuntura de saúde pública que conduziu à eleição dos seus três deputados e ao eventual enraizamento dos ideais republicanos na cidade. Através do nosso estudo, concluímos que a eleição dos deputados da peste (os três deputados do PRP eleitos no Porto em 1899) se deveu, principalmente, às condições que se viveram a partir de 1899 na cidade do Porto, não apresentando uma representação significativa nas eleições subsequentes.

Neste sentido, suportámos o nosso estudo na consulta de diferentes fontes: Fundo do Tribunal de Verificação de Poderes do Arquivo Histórico Parlamentar; Diário da Câmara dos Deputados (durante o período de março a junho de 1900); jornais, bem como fontes legislativas, especialmente a compilação de Legislação Eleitoral Portuguesa (1820-1926).

Palavras-chave: Eleições de 1899 a 1901, Porto, Partido Republicano Português, Deputados da peste, Peste bubónica de 1899.

\begin{abstract}
This paper focuses on the elections for the Chamber of Deputies from 1899 to 1901 in Porto, particularly considering the Portuguese Republican Party results, aiming to understand the impacts of electoral laws and of the public health conjuncture that led to the election of its three deputies and the eventual entrenchment of republican ideals in the city. Through our study, we conclude that the election of the plague deputies (the three deputies from the PRP elected on 1899) was mainly due to the conditions that were experienced from 1899 onwards in the city of Porto, not presenting a significant representation in subsequent elections.

In this sense, we support our study on different sources: Parliamentary Historical Archive - Fundo do Tribunal de Verificação de Poderes; Parliamentary Debates (during the period from March to June 1900); newspapers as well as legislative sources, mainly the compilation of Portuguese Electoral Legislation (1820-1926).
\end{abstract}

Keywords: 1899 to 1901 Elections, Porto, Portuguese Republican Party, Plague Deputies, Bubonic Plague of 1899. 


\section{Introdução}

A lei eleitoral e o momento das eleições revelam-se instrumentos essenciais para analisar a verdadeira aplicabilidade dos direitos, liberdades e garantias (os denominados DLG). Pretendemos, por isso, analisar de forma aprofundada, durante o período de 1899 a 1901, os impactos de tais questões na sociedade portuguesa, mais especificamente no Porto.

Apesar de alguns autores, na época do liberalismo português, considerarem as eleições uma «ficção constitucional» ${ }^{1}$, na realidade, até num país pautado pelo rotativismo partidário e onde a expressão da vontade popular não tinha carácter universal, as eleições permitem analisar o funcionamento do sistema político da época liberal, tendo em consideração as diversas funções que desempenhavam: v.g. "legitimação do poder político; recrutamento e seleção das elites políticas; controlo social, canalizando os conflitos, reais ou latentes, para o terreno legal"'2.

As eleições desempenhavam um papel crucial na organização e legitimação do poder político, são a engrenagem essencial que assegura, simultaneamente, a concretização da ideia de representação - concebida em termos individuais, e já orgânicos - e da de consenso - pela aceitação, por convenção tácita e unânime, do princípio da maioria como presunção «razão comum» ${ }^{3}$.

O ritmo acelerado a que ocorreu a profusão de reformas eleitorais, sobretudo no período da crise finissecular da Monarquia Constitucional, demonstra o quão instável era o clima político que se vivia no país, bem como a tensão entre as variadas facções ideológicas, o que nos leva a concluir que o estudo da matéria eleitoral é relevante na historiografia portuguesa.

Se é verdade que as múltiplas reformas legislativas efectuadas nem sempre se traduziram em alterações de vulto, ou induziram transformações significativas nas práticas e comportamentos políticos, o conjunto de inovações e soluções alternativas ensaiadas, é, todavia, suficientemente variado e rico para conferir um especial interesse ao estudo histórico da evolução do regime eleitoral no liberalismo. ${ }^{4}$

O Porto apresenta-se como uma das áreas com maior ${ }^{5}$ densidade populacional do país; além disso, as suas circunscrições urbanas permitem compreender o comportamento de um eleitorado mais activo politicamente face às áreas rurais. Ademais, o Porto revela-se, no período demarcado, uma arena em que os ideais republicanos têm um maior impacto na esfera pública, até porque é, sobretudo, este o partido que coloca em prática métodos de campanha eleitoral, com base no conceito contemporâneo que lhe atribuímos.

\footnotetext{
${ }^{1}$ ALMEIDA, P. Tavares de - "Comportamentos Eleitorais em Lisboa (1878-1910)". Análise Social. [Em Linha] Vol. XXI, n. ${ }^{\circ} 85$ (1985). p. 111.

${ }^{2}$ ALMEIDA, P. Tavares de - Eleições e Caciquismo no Portugal Oitocentista, 1868-1890. Lisboa: Difel, 1991, p. 16.

${ }^{3}$ ALMEIDA, P. Tavares de - "Comportamentos Eleitorais em Lisboa (1878-1910)"... p. 112.

${ }^{4}$ ALMEIDA, P. Tavares de - Legislação Eleitoral Portuguesa (1820-1926). Lisboa: Imprensa Nacional - Casa da Moeda, 1998, p. IX.

${ }^{5}$ De acordo com o Recenseamento Geral da População disponível no Instituto Nacional de Estatística, o número de habitantes no Porto em 1890 era de 146454; e, em 1900, de 165729.
} 
Importa realçar que o PRP surgiu como um partido que se posicionava claramente contra o status quo da época, ganhando ímpeto com a grave crise financeira que levou à bancarrota portuguesa, aliada à questão do Ultimatum de 1890, que culmina num período de exaltação e de descrença na Monarquia.

De entre as múltiplas críticas que o PRP fazia à Monarquia Constitucional, avultava aquela que considerava ser o seu pecado original:

ser uma instituição filosoficamente eclética, de estar a abrir as suas portas ao regresso das ordens religiosas e de, ao domesticar o radicalismo vintista e patuleia, ter criado um simulacro da representação nacional, deficiência que o bicameralismo avivava ainda mais. ${ }^{6}$

O PRP apresenta como um dos seus principais ideais, sobretudo na fase da propaganda (que incorpora os anos em questão nesta análise, isto é, antes do 5 de Outubro de $1910^{7}$ ), um manifesto que afirmava "uma vocação colectiva ao representarem a história do país como um palco em que, momentaneamente vitorioso ou derrotado, o pendor natural do povo português para a democracia se ia concretizando" 8 .

Destarte, numa cidade que já havia sido palco de uma tentativa de revolta republicana no início da década (o 31 de Janeiro de 1891), o que demonstra o enraizamento dos respectivos ideais no Porto, a República era então publicitada como provedora de felicidade universal, estando associada a um movimento milenarista, baseado na ilusão da possibilidade de cumprir um programa cuja total aplicação é uma ideia algo utópica, como os anos seguintes viriam a confirmar.

O motivo pelo qual escolhemos o referido arco temporal prende-se com o facto de permitir, em primeiro lugar, estudar e observar os impactos da legislação eleitoral de 18951896 (ligeiramente alterada em 1899), optando por este primeiro ano para compreender o motivo pelo qual a peste bubónica, o cordão sanitário decretado no diploma do governo de José Luciano Castro, e o ordenamento jurídico eleitoral em vigor (apesar de não o pretender) levaram à eleição de três deputados republicanos no Porto, os denominados "deputados da peste".

Prosseguimos a nossa pesquisa uma vez que, apesar do crescimento dos deputados republicanos no Porto e da repetição das eleições na cidade a 18 de Fevereiro de 1900, que vieram a confirmar a eleição dos deputados em causa, nas eleições subsequentes, mesmo tendose verificado um aumento dos votos a nível nacional, os republicanos acabaram por não conseguir carimbar nenhum mandato.

\footnotetext{
${ }^{6}$ CATROGA, Fernando - "O Republicanismo Português (Cultura, História e Política)". Revista da Faculdade de Letras - História. [Em Linha] Porto. III Série, vol. 11 (2010) p. 105.

${ }^{7}$ Concretamente no final dos anos 90 do séc. XIX, atendendo ao facto de a fase de propaganda republicana se ter caracterizado por momentos diferenciados

${ }^{8}$ Idem, p. 99.
} 
Por fim, pretendemos compreender os impactos nas eleições do Decreto de 8 de Agosto de 1901, que produz uma nova lei eleitoral, conhecida como a "ignóbil porcaria", que visou pacificar o clima de tensão com base na premissa de atenuar os danos da ruptura franquista e combater o crescimento do PRP. Esta lei permitiu um maior controlo dos atos eleitorais por parte do Governo, através da manobra que dividiu o país em grandes círculos, enquanto o Porto e Lisboa eram desenhados para que os votos rurais anulassem os votos urbanos.

Quanto ao corpo documental, encontrámos nas diversas fontes do Arquivo Histórico Parlamentar selecionadas o ponto basal de referência para o desenvolvimento da nossa investigação ${ }^{9}$. Estas constituem uma documentação maioritariamente manuscrita, com a excepção dos cadernos de recenseamento que se encontram dactilografados, e que têm, na maioria dos casos, diversas páginas, mas em número bastante distinto entre si. Alguma documentação apresenta contradições entre si; por exemplo, o número de entrada de listas, em diversas ocasiões, diverge do apuramento final do Tribunal de Verificação de Poderes face ao número que encontrámos após contabilizar os cidadãos que votaram através dos cadernos de recenseamento ${ }^{10}$.

Face ao exposto, acreditamos que este tema é ilustrativo do fenómeno político e institucional que vigorava na transição do século XIX para o século XX, pelo que procuramos estudar detalhadamente as fontes relativas a estas eleições, com o intento de cumprir a missão de enriquecer o conteúdo que visa explorar o papel das eleições no liberalismo português e a proliferação do republicanismo em Portugal.

\footnotetext{
${ }^{9}$ Todas as caixas referentes às eleições, que muitas vezes se encontram divididas em maços, contêm em duplicado os cadernos dos cidadãos eleitores, assim como os mapas de apuramento de votos por cada assembleia de voto, as actas da constituição da mesa eleitoral e as actas das eleições, onde encontrámos o apuramento dos resultados por cada candidato no respectivo local. Observámos ainda, em alguns casos, os protestos feitos por cidadãos e os respectivos pareceres do Tribunal de Verificação de Poderes. Cada eleição, exceptuando a de 1901, apresenta um acórdão com uma avaliação do cumprimento das regularidades do acto eleitoral e um documento com o total de votos por candidato. Por vezes, verificámos também a existência de listas inutilizadas, isto é, dos votos considerados nulos.

${ }^{10}$ Das demais fontes, a consulta dos Debates Parlamentares circunscritos ao hiato temporal em causa têm como principal fim a análise do papel dos "deputados da peste" na Câmara dos Deputados. Já os documentos de natureza hemerográfica possibilitam compreender o contexto político e as atividades de campanha do Partido Republicano Português nos períodos de eleição, nomeadamente em relação à primeira eleição em consideração, a de 1899. As fontes legislativas permitem compreender a regulamentação da matéria eleitoral, bem como fazer uma comparação das diferenças materiais entre as diversas leis. Por fim, a documentação epistolar são cartas de natureza pessoal, não tendo necessariamente de ser fiéis a uma outra realidade do que aquela formulada pelo emissor. No entanto, sobretudo a correspondência trocada com Hintze Ribeiro releva por conter os planos e perspectivas referentes ao surgimento da "ignóbil porcaria", naquilo que ficou conhecido como o regime concubinário Hintze-Luciano.
} 


\section{Contextualização Histórica}

No final do século XIX, a monarquia portuguesa apresentava já sinais da sua debilidade no panorama político. Em boa verdade, os partidos tradicionais do regime encenavam já diversas estratégias de bastidores para dirimir o avanço no terreno das facções antimonárquicas, mormente o PRP.

Um dos principais mecanismos de constrição era precisamente o uso de estipulações normativas na legislação eleitoral. O período em consideração é rico em alterações à legislação eleitoral, o que ocorre como uma forma dos governos sedimentarem o seu poder, não sendo assim postos em causa pelo generalizado descontentamento da população portuguesa e pelos novos movimentos que proliferam, tentando incapacitá-los.

Na viragem do século a sociedade portuguesa era uma sociedade complexa e plural, dividida pelas tensões entre grupos sociais e pólos regionais. O problema do sistema político é que os grupos sociais tendiam a exigir uma resposta, a par e passo, às suas dificuldades, de tal ordem que a única salvação para o sistema seria conseguir transformar-se num espelho harmónico da sociedade. Os grupos não reconheciam competência aos políticos para escolherem, para decidirem. ${ }^{11}$

Referente à reforma eleitoral de 1896, que seria confirmada pela que lhe sucedeu em 1899, da autoria de um governo progressista, um dos seus objectivos era "diluir o impacto do voto republicano nos dois principais centros urbanos, através da mobilização clientelista do eleitorado dos chamados «burgos podres»" "12, e se, em 1899, os três deputados eleitos pelo Porto são membros do PRP, podemos perguntar se os propósitos da nova lei surtiram os efeitos pretendidos.

Para tal, importa contextualizar que a primeira eleição em análise, a de 26 de Novembro de 1899, foi marcada pelo facto de "o Porto ser a primeira cidade da Europa a ser atingida pela terceira pandemia da peste, suportando durante quatro meses um cerco sanitário imposto militarmente pelo governo nacional"13 , coincidindo com a eleição de três deputados republicanos.

No dia 4 de Setembro de 1899, o Porto parece uma cidade vazia. Sobe-se da rua do Infante até à rua das Flores, praça Almeida Garrett e daí até à rua de Santo António e por todo o percurso encontra-se comércio de portas fechadas. Não, não é feriado: desde o último dia de Agosto que os estabelecimentos estão encerrados, em sinal "luto." Este é o protesto silencioso contra o cordão militar que, há mais de uma semana, isola a cidade do resto do país. Um cerco foi decidido pelo governo de Lisboa depois de precisamente há dois meses, a 4 de Julho, o médico municipal, Ricardo Jorge, ter recebido uma nota de um comerciante que lhe dava conta de umas mortes estranhas entre carregadores que moravam na rua da Fonte Taurina, junto ao Douro. Era a peste ${ }^{14}$.

\footnotetext{
${ }^{11}$ RAMOS, Rui - A Segunda Fundação 1890-1926, Vol. 6 In J. Mattoso (org.), "História de Portugal”, Lisboa, Editorial Estampa, 2001, p. 217.

${ }^{12}$ ALMEIDA, P. Tavares de - Legislação Eleitoral Portuguesa (1820-1926)... p. XXXII.

${ }^{13}$ PONTES, David - O cerco da peste no Porto: cidade, imprensa, saúde pública na crise sanitária de 1899. [Em Linha] Porto: Dissertação apresentada para a obtenção do grau de Mestre em História na Faculdade de Letras da Universidade do Porto, 2012. p. 99.

${ }^{14}$ Idem, p. 8.
} 
O combate à situação pandémica ficara a cargo do médico Ricardo Jorge, especialista em saúde pública. Devido ao impacto nefasto que esta conjuntura começara a desenvolver, a Junta Consultiva de Saúde Pública, órgão dependente do Ministério do Reino e que vinha a observar a evolução dos episódios desde Julho, propôs um conjunto de medidas ao Governo chefiado pelo líder do Partido Progressista José Luciano de Castro, vieram a ser enquadradas normativamente no Decreto de 17 de Agosto de 1899.

Das diversas medidas que este elencava, destacamos a supressão de todos os eventos que promovessem entradas e saídas de grande quantidade de pessoas na cidade (v.g. romarias, feiras) - o objectivo seria evitar a possibilidade de aglomerado de pessoas, o que promoveria a disseminação da doença; a inspeção médica dos passageiros dos comboios à saída do Porto e à chegada aos seus locais de destino e a desinfeção das bagagens e mercadorias. Este era o quadro administrativo-normativo que tentaria acalmar a calamidade pública que se vivenciava.

Não obstante, não se revelaria suficiente esta tomada de posição. A Junta foi levada a recomendar uma acção preventiva mais rigorosa e premente na restrição dos direitos fundamentais dos cidadãos portuenses. Por conseguinte, a 23 do mesmo mês, o Governo decretava a criação de um cordão sanitário, determinando que

as pessoas, bagagens e mercadorias procedentes do Porto, somente poderão ter saída pelos pontos e nos termos que forem regulados pelo Governo, para um comboio especial, que as conduza a um lazareto que se instalará na Granja, onde serão feitas as quarentenas e desinfeções respetivamente aplicáveis, para que possam seguir o seu destino ${ }^{15}$.

Estes dois decretos geraram um pujante descontentamento da população do Porto, nomeadamente nos grupos de interesses comerciais da cidade, que viam temerosamente obstaculizados o exercício das suas actividades mercantis e o desenvolvimento económico local, devido às limitações à livre circulação de pessoas e de mercadorias. Representados pela Associação Comercial do Porto (ACP), a Associação Industrial Portuense e o Centro Comercial do Porto, assumiram-se como uma das forças mais empenhadas no combate às medidas decretadas pelo Governo pois temiam as consequências nefastas dessas limitações.

Em simultâneo, a imprensa portuense, nomeadamente O Comércio do Porto e o Jornal Notícias, encetava uma campanha agressiva contra o Executivo e a Junta Consultiva de Saúde Pública. Aliás, O Comércio do Porto defendeu mesmo que, por trás dos decretos, haveria a intenção de enfraquecer a próspera economia do Porto. Todo este movimento teve fortes repercussões na opinião pública local, o que se revelará um elemento chave para compreender a eleição dos três "deputados da peste"

\footnotetext{
${ }^{15}$ Decreto de 17 de agosto, In Coleção Oficial de Legislação Portuguesa - Ano de 1899, Lisboa, Imprensa Nacional, 1900, p. 353, apud. PONTES, David - O cerco da peste no Porto...

${ }^{16}$ Cfr. PONTES, David - O cerco da peste no Porto... pp. 36-38.
} 
Assistiu-se a uma grande mobilização da população no sentido de levantar as restrições, implementadas pelas medidas sanitárias impostas pelo Governo. Sem embargo, as mesmas foram goradas. Como forma de protesto, no dia 1 de Setembro os estabelecimentos comerciais fecharam, após tomada de decisão de comerciantes no Palácio da Bolsa a 31 de Agosto de 1899.

Vivia-se no Porto uma recessão, em que o encerramento das empresas locais levara à fome e ao desemprego - uma situação de carestia. Devido a este panorama e às hostilidades da imprensa, a 4 de Outubro, o Governo aprovou um decreto "lei da rolha", em que estabelecia a suspensão e até mesmo a supressão de todos os periódicos que negassem a existência pandémica da peste bubónica no Porto e que, consequentemente, apresentassem críticas ou injúrias ao papel das autoridades públicas no seu combate.

Não obstante, durante esse mês e os seguintes, a indagação e a aguerrida revolta continuaram a caracterizar a imprensa da cidade, demonstrando que as mesmas permaneciam igualmente vivas entre a elite portuense. Aliás, esta teria, em breve, o meio mais poderoso para punir o Governo pelas ofensas à cidade: as eleições legislativas, que decorreriam a 26 de Novembro de $1899^{17}$. Não seria exclusivamente uma forma da população castigar a força executiva vigente, mas também uma forma de as forças da opressão se insurgirem contra esta, o que o PRP aproveitara de forma estratégica. Em específico, o PRP apresentava já estruturas de mobilização semelhantes às que existem atualmente.

Fundamentalmente, pela organização de actos políticos de natureza colectiva (os meetings). A propaganda republicana utilizava a imprensa, distribuía manifestos, recorria a conferência e comícios eleitorais e apoiava-se numa bem montada estrutura organizativa, com muitos centros locais e comissões paroquiais, que lhes permitia cobrir todos os bairros da cidade ${ }^{18}$.

Portanto, desta forma e simultaneamente conexionado com o apoio da imprensa, o PRP conseguirá fazer eleger três deputados nas eleições de 26 de Novembro de 1899.

Contudo, essa mesma eleição foi alvo de anulação por parte do Tribunal de Verificação de Poderes, como forma de os progressistas tentarem minimizar o gesto.

Até 1895 a verificação dos poderes dos Deputados era do âmbito da própria Câmara que, em sessão preparatória, procedia à eleição da(s) Comissão(ões) de Verificação dos Poderes, a fim de examinar a legitimidade dos candidatos eleitos e a legalidade do ato da eleição. Esta verificação, ou exame, é regulamentado pelo regimento da Câmara, pela Carta Constitucional e lei eleitoral. A partir dessa data é determinado que a verificação dos poderes dos Deputados passava a ser feita fora da Câmara por pessoas escrutinadas para o efeito e que se constituíam em Tribunal de Verificação de Poderes para executar as mesmas funções das anteriores comissões. Esta situação verifica-se até 1910, fim da monarquia. Pela carta de lei de 26 de Julho de 1899, no artigo 95. ${ }^{\circ}$, refere-se: "o tribunal de verificação de poderes tem por fim conhecer todos os processos das eleições de deputados julgando as reclamações ou protestos, declarando válidas ou nulas as mesmas eleições."

\footnotetext{
${ }^{17}$ Cfr. Idem, pp. 78-79.

${ }^{18}$ ALMEIDA, P. Tavares de - “Comportamentos Eleitorais em Lisboa (1878-1910)”... pp. 129-130.
} 
O Tribunal de Verificação de Poderes era composto pelo presidente do Supremo Tribunal de Justiça, que era o presidente, por 3 juízes do mesmo tribunal designados "pela sorte", por 3 juízes da Relação de Lisboa e 2 da Relação do Porto, também designados "pela sorte". Tem um regulamento próprio aprovado em sessão do tribunal em 4 de Dezembro de $1899^{19}$.

Apesar do acima exposto, a 18 de Fevereiro de 1900, na repetição das eleições exclusivamente no círculo eleitoral n. $^{\circ}$ 25, o do Porto, os três deputados republicanos (Afonso Costa, Paulo José Falcão e Francisco Xavier Esteves) foram reeleitos.

No entanto, passados uns meses, na eleição de 25 de Novembro de 1900 e no ano seguinte, em 1901, na eleição de 6 de Outubro, os mesmos já não conseguiram obter assento parlamentar, tendo-se até verificado um aumento dos votos a nível nacional.

Para estas últimas eleições importa contextualizar que face à respectiva situação, verificava-se igualmente um tumultuoso período de crise política cristalizado no crescimento generalizado do PRP nas áreas urbanas, e no surgimento de um novo movimento que ameaçava o sistema - o «franquismo» - isto porque em Maio de 1901, Hintze e Franco entravam num ponto de cisão,

esta divisão não limitou os seus efeitos a um enfraquecimento do partido no poder; pelo trajecto ideológico e político do próprio João Franco, e na conjuntura em que se processou, assumiu o sentido de uma ameaça ao sistema partidário, baseado na alternância governativa entre regeneradores e progressistas ${ }^{20}$.

Hintze Ribeiro dissolve a Câmara dos Deputados a 4 de Julho e, pelo decreto de 8 de Agosto de 1901, produz uma nova lei eleitoral, que ficaria conhecida até aos dias de hoje como a "ignóbil porcaria". Afigurava-se como uma forma de pacificar a situação, com base no combate à proliferação das ideias do PRP, e de atenuar os danos da ruptura franquista, permitindo assim um maior controlo dos atos eleitorais por parte do Governo, através da manobra de o país ser "dividido em grandes círculos plurinominais, com as cidades de Lisboa e Porto desenhadas de forma a que os votos urbanos fossem anulados pelos rurais" ${ }^{21}$.

Tal alteração legislativa terá um peso determinante no processo eleitoral e no apuramento dos seus resultados finais.

\footnotetext{
${ }^{19}$ História Administrativa e Biográfica do Tribunal de Verificação de Poderes.

${ }^{20}$ SOBRAL, José Manuel; ALMEIDA, Pedro Tavares de - "Caciquismo e poder político. Reflexões em torno das

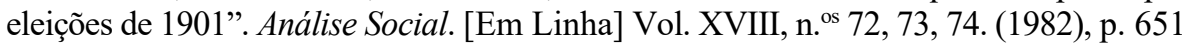

${ }^{21}$ MÓNICA, Maria Filomena - “As Reformas Eleitorais no constitucionalismo monárquico, 1852-1910”. Análise Social. [Em Linha] Vol. XXXI, n. ${ }^{\circ} 139$ (1996), p. 1068.
} 


\section{Motivos que levaram às alterações legislativas em matéria eleitoral}

\subsection{Decreto de 28 de Março de 1895}

No início desta década, o país viveu um período nebuloso devido à crise financeira e ao exacerbar de uma vaga de índole nacionalista que se fizera sentir face aos problemas diplomáticos com a Inglaterra, consequências do ultimato inglês de 1890.

De tal forma, a 22 de Fevereiro de 1893, o Rei pedia a Hintze Ribeiro, do Partido Regenerador, para encabeçar um governo, levando consigo João Franco, Bernardino Machado e Augusto Fuschini, nomes que, no final do ano, já haviam solicitado demissão.

Nas eleições que ocorreram em Abril de 1894, os regeneradores obteriam a maioria. No entanto, nem tudo correria como desejado pelos dois partidos do sistema: se, por um lado, o Partido Progressista apresentava dissidências que beneficiavam, por exemplo, os republicanos, o Partido Regenerador veria Augusto Fuschini a aliar-se a Dias Ferreira contra Hintze, que encabeçava o Governo. Em Novembro, o Parlamento era encerrado, apesar de não se ter verificado nenhuma marcação de eleições por parte do Executivo.

Para João Franco, a ditadura era o único meio viável para renovar a composição da Câmara dos Deputados, sendo para tal necessário uma alteração à lei eleitoral, o que ocorreria a 28 de Março de $1895^{22}$.

\subsection{Lei de 21 de Maio de 1896}

Todavia, face ao Decreto acima mencionado, aquilo que se verificou foi uma rejeição total deste por parte dos partidos da oposição. Aliás, estes partidos abstiveram-se nas eleições de Novembro de 1995. José Luciano de Castro, inclusive, em propaganda contra o Decreto, argumentou que ainda mais importante que uma forma de governo monárquica, era a questão da liberdade.

Esta situação teve como consequência um Parlamento monopartidário, sob a presidência de Hintze Ribeiro, o que levaria a que João Franco tivesse de apresentar uma nova reforma eleitoral, lei aprovada a 21 de Maio de 1896.

Cunha Pimentel explicou, por fim, o motivo que havia levado o governo a recuar: «As circunscrições eleitorais mais largas demandam, para o aperfeiçoamento do regime parlamentar, uma perfeita organização partidária e uma educação política que entre nós não existe ainda. A experiência veio demonstrar que ainda era cedo e o governo, vendo que um partido importante se afastou da urna, e da vida parlamentar, tomava como pretexto o alargamento dos círculos, julgou mais importante anuir à vontade soberana dos

\footnotetext{
${ }^{22}$ De notar que esta alteração legislativa tem precisamente a denominação de Decreto e não de Lei, como as seguintes, por ter sido realizada numa fase de ditadura, isto é, num período em que o Parlamento não se encontrava em funcionamento.
} 
Representantes da Nação e voltar aos círculos uninominais.» Numa palavra, o Executivo cedera à pressão dos Progressistas ${ }^{23}$.

\subsection{Lei de 26 de Julho de 1899}

Esta lei será emitida num período em que o Governo é chefiado pelo Partido Progressista, na figura de José Luciano Castro, não tendo nenhum motivo em particular de relevância como causa da sua alteração.

\subsection{Decreto de 8 de Agosto de 1901}

A denominada "ignóbil porcaria", de todas as alterações à legislação eleitoral, foi a que mais intuito teve de prejudicar as facções políticas que não pertenciam aos partidos do rotativismo vigente. Se, numa primeira análise, consideramos que a ameaça republicana é a que mais inquieta as forças políticas monárquicas, um olhar mais atento, permite-nos facilmente perceber que a grande ameaça é João Franco e os seus apoiantes: o franquismo.

Se em Novembro de 1899 eram eleitos os três "deputados da peste" (reeleitos em Fevereiro de 1900), aquilo que observamos é que tal ocorreu devido à influência de João Franco.

Nas eleições do Porto tinham sido João Franco e os seus amigos Campos Henriques e José Novais quem apoiara os candidatos republicanos (Correio da Noite, de 19 de Fevereiro de 1900). Aliás, no Parlamento, João Franco andava aos abraços a Afonso Costa. «Ainda o vemos republicano», dizia um «hintzáceo», citado pelo Correio da Noite (3 de Maio de $1900) \cdot{ }^{24}$

José Luciano Castro, com a saúde cada vez mais débil, depois de três anos de governo cedeu o seu lugar e o Partido Regenerador tomou novamente o poder. Após a morte de António Serpa, a 23 de Março de 1900, Hintze "era declarado oficialmente chefe do Partido Regenerador"25.

Em 1900, em Julho, João Franco não será convidado para o governo chefiado por Hintze, que, por sua vez, tentara captar apoiantes franquistas. No entanto, nas eleições que ocorreram no final do ano, Franco e alguns dos seus companheiros eram eleitos como deputados enquanto parte integrante da maioria regeneradora. Todavia, apesar de o clima dentro do partido parecer em colisão iminente, na realidade, demorou algum tempo até se dar a cisão definitiva.

Aparentemente, a «gente de Hintze», queria romper, mas os amigos de Franco andavam mansos, evitando dar motivos (carta de José Alpoim de 5 de Janeiro de 1901, em Correspondência de J. Luciano, na Anadia, caixa 2, n. ${ }^{\circ} 160$ ). A 13 de Fevereiro, Franco desagradou Hintze com um discurso sobre concessões no ultramar, tendo este reagido um pouco agastado. Mas nem então vieram às mãos. Só a 14 de Maio o deputado «franquista» Malheiro Reimão se atrevia a atacar o Governo por causa do projecto de contribuição predial. Disse-se depois que a declaração de hostilidade por parte de Reimão desagradara a Franco, que a achou

\footnotetext{
${ }^{23}$ MÓNICA, Maria Filomena - “As Reformas Eleitorais no constitucionalismo monárquico, 1852-1910”... p. 1067.

${ }^{24}$ RAMOS, Rui - A Segunda Fundação... p. 220.

${ }^{25}$ Idem, ibidem.
} 
prematura. Mas no dia seguinte ele seguia o seu camarada, carregando também contra o projecto de lei. Era finalmente, a crise, Franco levou com ele 25 deputados regeneradores ${ }^{26}$.

Se o Partido Regenerador estava dividido a meio e uma crise política se instalava, com o apoio de D. Carlos, Hintze tem todos os meios a seu dispor para combater o seu ex-companheiro de Governo. De tal modo, em Julho de 1901, em plena agitação, o Parlamento será dissolvido. É neste contexto que irá surgir o Decreto de 8 de Agosto de 1901. Apesar de não nos focarmos agora nas alterações e como elas afectaram quer os franquistas, quer os republicanos, analisaremos os preparativos que levaram a publicar este Decreto, mais concretamente na cidade do Porto, local onde efectivamente os republicanos eram a "praga" a dizimar.

Como veremos, será Hintze Ribeiro, que à época era presidente do Ministério, a tomar a iniciativa de propor um pacto eleitoral com José Luciano Castro, isto é, uma aliança com os progressistas, quer na eleição para a Câmara dos Deputados de 6 de Outubro de 1901, quer para as municipais de 3 de Novembro de 1901. O objectivo era criar mecanismos, através de uma reforma eleitoral, que impedissem a entrada de João Franco e dos seus camaradas no Parlamento. Tal ligação ficará conhecida como o "regime concubinário de Hintze-Luciano".

Uns e outros partilhavam então o receio de que a irrupção na cena política de um novo agrupamento chefiado por um líder forte como João Franco viesse acicatar a discórdias nas fileiras dinásticas e abalar a tradicional hegemonia e alternância no governo dos partidos da rotação. A par dessa preocupação comum, convergiam também no imediato distintas conveniências tácticas. Para o partido governamental, que precisava de reconstruir a sua debilitada maioria parlamentar, um folgado triunfo eleitoral e, em particular, a severa punição dos «cisionistas» era uma necessidade imperiosa; mas sem um aliado sólido, e tendo de dispersas as suas depauperadas forças na luta contra vários contendores ou até de enfrentar uma coligação adversária, os regeneradores corriam o risco de sofrer um sério desaire.

Por sua vez, para o Partido Progressista, o acordo tinha a vantagem de lhe garantir, a par de outras contrapartidas a nível local, uma representação parlamentar mais ampla com as «comodidades de uma eleição fácil e barata» ${ }^{27}$.

Apesar da instabilidade que se vivia, o grande foco desta aliança era diminuir as hipóteses dos franquistas, que eram a grande preocupação de Hintze Ribeiro. Aliás, na correspondência trocada entre ele e José Luciano de Castro tal é bastante explícito. É disso exemplo o seguinte trecho:

Castelo-Branco: percebi que o Hintze estava aflito, preocupadíssimo e, evidentemente, resolvido a tudo, ainda $\mathrm{cm}$ risco de graves consequências, no círculo de Castelo-Branco. A solução Tinalhas ${ }^{28}$, registou-a. Palavras textuais: «Dissolvi a Câmara e faço uma campanha eleitoral, devendo esse grande favor ao Rei, que sabe bem para que o faço... jogo tudo por tudo... pode o acaso ou a má-sorte ser-me desagradável em alguns pontos... prefiro isso a

\footnotetext{
${ }^{26}$ Idem, p. 221.

${ }^{27}$ ALMEIDA, P. Tavares de - Nos Bastidores das Eleições de 1881 e 1901: Correspondência política de José Luciano de Castro. Lisboa: Livros Horizonte, 2001, p. 82.

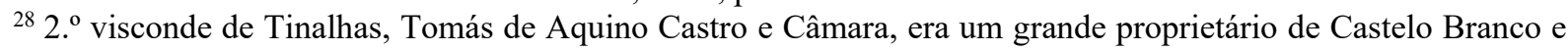
apoiante de João Franco.
} 
ceder, seja no que for, no caminho que tracei e a, pela minha mão, vir à Câmara qualquer deputado franquista, seja ele quem for» ${ }^{29}$.

Hintze, empenhado em criar os maiores obstáculos a João Franco, assume que, com auxílio do Rei, fará de tudo para o conseguir derrotar e para que não tenha assento parlamentar. Surgirá assim a "ignóbil porcaria".

Porém, a reforma eleitoral não se mostrará suficiente; ainda depois dela, é necessário unir esforços para derrotar os inimigos comuns e manter o status quo da época. A 17 de Agosto de 1901, o líder do Partido Progressista escreve a Hintze o seguinte:

Permita-me agora a V. Ex ${ }^{a}$ que lhe diga que eu faço o que posso para me desempenhar do voto de confiança que recebi dos meus am. ${ }^{\text {ss }}$ para dirigir a campanha eleitoral, conciliando quanto possível os interesses do meu partido com os do governo, a quem por considerações de ordem pública não desejo criar dificuldades ${ }^{30}$.

Estava assim firmado o pacto entre estes dois partidos. Auxiliaram-se mutuamente, inclusive junto dos caciques do poder e durante as épocas eleitorais, de forma a garantir apenas a sua permanência na Câmara dos Deputados.

Apesar de aliados todos os esforços, até ao momento das eleições de 6 de Outubro de 1906, encontram adversidades em algumas cidades. Tendo em consideração que uma das cidades que causou maior ansiedade aos líderes monárquicos foi o Porto, devido a quezílias com os republicanos, importa analisar os seguintes fragmentos:

Envio a V. Ex. ${ }^{a}$ essa carta do Lima Jr. Chegam aqui notícias de que se fazem várias combinações no Porto: por carta do Teix. ${ }^{a}$ de Sousa sei que o Hintze está preocupadíssimo, temendo votos discordantes - este é o termo usado. Conhece V. Ex. ${ }^{\mathrm{a}}$, melhor do que eu, as coisas e pessoas do Porto... O que haverá? Quererão discutir a maioria? É um perigo, e pode isso prejudicar a nossa política geral. O que eu julgava mais útil seria alcançar as minorias e tirar as vantagens locais que fossem decentes arrancar ${ }^{31}$.

E estou certo de que os seus amigos políticos do Porto atenderão às recomendações de V. Ex. ${ }^{\mathrm{a}}$, concorrendo com os regeneradores na cidade do Porto, afim de que os republicanos não apareçam com votação superior à que podem ter. Informação do Pereira e Cunha dizme que os republicanos, ainda com uma última reunião resolveram ir à urna ${ }^{32}$.

Porto. Recebi uma carta desesperada do Lima. Abstêm-se: mas vigiam as urnas para os republicanos terem maioria!

Já viu V. Ex. ${ }^{a}$ uma coisa assim?! Era mais do que puerilidade o que eles queriam! Se V. Ex. ${ }^{a}$ não intervém, a asneira é certa. Eu escrevo ao Lima, insistindo no que V. Ex. ${ }^{a}$ diz (e que é o que lhe tenho escrito dúzias de vezes) e mostrando que a sua atitude de uma abstenção activa em favor dos republicanos é um erro, um mau passo... e um acto que será explorado contra o partido. ${ }^{33}$

\footnotetext{
${ }^{29}$ ALMEIDA, P. Tavares de - Nos Bastidores das Eleições de 1881 e 1901 ... pp. 90-91.

${ }^{30}$ Idem, p. 110.

${ }^{31}$ Idem, p. 111.

${ }^{32}$ Idem, p. 155

${ }^{33}$ Idem, p. 111.
} 
Nesta senda, em relação às eleições no Porto, aquilo que observamos é que alguns membros dirigentes do Partido Progressista da cidade, que tinham sido impedidos de se candidatarem, pretendiam que num dos círculos fosse atribuída a maioria ao seu partido, não concordando com a visão política da aliança firmada. Para os Progressistas ficaram apenas os lugares das minorias.

Para tal, estes ameaçam e apresentam uma vigorosa chantagem, em que, caso não lhes fosse dado o que pretendiam, iriam apoiar os republicanos. Foi assim posto em causa o acordo eleitoral já mencionado, o que criou diversas intrigas e desconforto no seio do Partido Progressista. Não obstante, tal situação foi passível de harmonização e não foi posta em causa a eficácia da aliança, visto que os republicanos nessas eleições não conseguiram eleger nenhum deputado no Porto.

Podemos assim considerar que, apesar de a "ignóbil porcaria" ser um mecanismo que pretendia, primeiramente, combater João Franco e os seus apoiantes, o PRP avultava também um problema das forças políticas do sistema, nomeadamente na cidade do Porto, como acabámos de analisar.

Sem embargo, face aos resultados eleitorais nacionais, concluímos que a vitória e os objectivos foram cumpridos: é inegável que o seu saldo final foi positivo. O Partido Regenerador alcançou uma maioria parlamentar de ampla margem, 107 deputados num total de 155. Os Progressistas alargam a sua representação, passando de 32 deputados na eleição de 1900 para uma representação de 41 deputados. De realçar que foram ainda eleitos 6 deputados independentes que pertenciam a listas preparadas por ambos os partidos.

Por fim, o principal alvo a abater, os franquistas, apenas conseguiram a eleição de um deputado por Arganil. Republicanos e Católicos não conseguiriam sequer obter representação parlamentar. Estavam desta forma praticamente destruídas todas as forças que representavam uma situação de perigo para o sistema rotativista, e que consideravam de comum interesse político.

Escrevo a V. Ex. ${ }^{\mathrm{a}}$ depois de falar com o Hintze, de q. ${ }^{\mathrm{m}}$ fui colher as últimas notícias. Está contente como um Cuco! E sabe que, se não fossem os progressistas de Coimbra (apesar da deserção de alguns) teria levado uma sova. ${ }^{34}$

Os respectivos resultados só foram possíveis devido à união e apoio dos Progressistas e Regeneradores, como explicita Hintze Ribeiro numa carta a José Luciano de Castro:

Terminaram, felizmente as eleições de deputados, e creio V.Ex. ${ }^{a}$ não terá recebido de mim motivo de desgosto, como, pela minha parte, só tenho de agradecer a V.Ex. ${ }^{\mathrm{a}}$ a boa vontade que pôs em tudo o que era de superior e comum interesse político. ${ }^{35}$

\footnotetext{
${ }^{34}$ Idem, p. 174

${ }^{35}$ Idem, p. 176.
} 


\section{Principais alterações na matéria eleitoral}

Nesta análise serão referenciadas apenas as alterações legislativas mais relevantes e que tiveram mais impacto.

\subsection{Decreto de 28 de Março de 1895}

De forma geral, podemos indicar que são seis as principais novidades que este Decreto apresenta. Assistimos a uma redução da capacidade eleitoral. Se outrora poderia ser reivindicado o estatuto de «chefe de família», segundo a nova redação do artigo $1 .{ }^{\circ}$, apenas passariam a vigorar duas circunstâncias, não cumulativas, para ser eleitor:

\footnotetext{
São eleitores para cargos políticos a administrativos todos os cidadãos portugueses, maiores de vinte e um anos e domiciliados em território nacional, em que concorra alguma das seguintes circunstâncias:

$1 .^{\circ}$ Ser colectado em uma ou mais contribuições directas do estado por quantia não inferior a 500 réis;

2. ${ }^{\circ}$ Saber ler e escrever. ${ }^{36}$
}

Tal alteração surge com base no pretexto do elevado número de cidadãos que, ao abrigo da antiga disposição, se haviam recenseado, o que teria contribuído para a corrupção do voto. Mas a verdade é que com a nova lei se conseguia uma grande diminuição do corpo eleitoral que visava impedir o crescimento do PRP, visto que as camadas urbanas mais desfavorecidas, base eleitoral dos republicanos, teriam uma menor representatividade.

Em segundo lugar, assistimos a uma redução do número de deputados de 170 para 120.

Os artigos $4 .^{\circ}$ e $5 .^{\circ}$ do Decreto de Lei alargavam as inelegibilidades para os cidadãos se candidatarem a deputados. Os artigos $8 .^{\circ}$ e $9 .^{\circ}$ apresentam uma cota para a representação de certas classes, entre as quais as dos funcionários públicos e dos profissionais liberais, o numerus clausus para os primeiros era de 40 e, para os segundos, de 20.

O capítulo III do diploma legal em análise, nos seus artigos $14 .^{\circ}$ e seguintes, reorganizava a forma como se procediam os recenseamentos, permitindo assim que o Executivo tivesse um maior controle.

Passava a haver, assim, duas modalidades para a inscrição dos eleitores, apesar do recenseamento não ser obrigatório: aqueles que pagavam as contribuições, à partida, seriam automaticamente recenseados, e, aos funcionários públicos aconteceria o mesmo, uma vez que os respectivos ministérios se encarregavam de fornecer os dados necessários para tal; já os cidadãos que invocavam a categoria de alfabetizados (saber ler e escrever) teriam de tomar por

\footnotetext{
${ }^{36}$ Artigo 1. ${ }^{\circ}$ do Decreto de 28 de Março de 1895.
} 
si a iniciativa de se inscreverem, sendo necessário cumprir um vasto conjunto de procedimentos, o que dificultava o processo.

Todavia, na prática, vão verificar-se, amiúde, ilegalidades por parte das entidades competentes do recenseamento.

Nos principais centros urbanos, os republicanos procuravam exercer uma vigilância apertada sobre as operações de recenseamento, embora os meios ao seu alcance não lhes permitissem muitas vezes a rectificação das irregularidades, mas tão-só a sua denúncia pública. As obstruções e arbitrariedade cometidas assumiram, em determinados períodos, tais proporções que, como ironicamente comenta João de Meneses, «um cidadão [...] tem mais dificuldades em ser recenseado do que em ser ministro, conselheiro ou visconde». ${ }^{37}$

A introdução de maior relevância neste Decreto de 28 de Março de 1895 é a que retoma o escrutínio por lista em todo o país, que viria a ser a questão que suscitaria uma grande polémica. As eleições de deputados passam assim a ser directas e as normas dispositivas desta matéria estão estipuladas no capítulo IV, artigos $40 .^{\circ}$ e seguintes do Decreto.

Os círculos seriam plurinominais e com o escrutínio de lista completa em todo o território nacional, correspondendo a 17 círculos eleitorais, coincidentes com os distritos. Visava-se desta forma impedir a entrada de membros do PRP no Parlamento.

Nenhum partido da oposição pode, sob este regime, disputar agora na urna a sua representação no Parlamento. Seja qual for a força de algum dos partidos oposicionistas em Lisboa, no Porto, ou em qualquer outra cidade independente, sejam quais forem as indicações da opinião dos eleitores mais esclarecidos, o Governo e os seus agentes abafarão tudo isso com as votações sertanejas, sempre arranjadas no nosso país por processos fraudulentos e infames para os governos conquistarem a maioria. ${ }^{38}$

\subsection{Lei de 21 de Maio de 1896}

Devido às circunstâncias já analisadas, esta lei estipulava que, nas províncias, voltassem a vigorar os círculos uninominais, visto que isso permitia que a oposição conseguisse eleger alguns deputados. Nas cidades, Lisboa e Porto, continuaria em prática a existência de círculos plurinominais.

Esta alteração assentava na ideia de que apenas a população da cidade estaria capaz de votar em listas. A população do resto do País era perspetivada como mais atrasada.

A ilustração destes centros populosos, a fácil e pronta inteligência em que aí podem entrar os eleitores para a combinação da lista múltipla e a quase identificação dos interesses das duas cidades com os grandes industriais e comerciais do país são elementos que aconselham um regime eleitoral diverso. ${ }^{39}$

\footnotetext{
37 TRINDADE COELHO - Manual Político do Cidadão Português, Lisboa: [s.n.], 1906. p. 473, apud. ALMEIDA, P. Tavares de - "Comportamentos Eleitorais em Lisboa (1878-1910)"... p. 125.

${ }^{38}$ A Vanguarda de 31 de Março de 1895, apud. ALMEIDA, P. Tavares de - "Comportamentos Eleitorais em Lisboa (1878-1910)"... p. 127.

${ }^{39}$ MÓNICA, Maria Filomena - “As Reformas Eleitorais no constitucionalismo monárquico, 1852-1910”... p. 1066.
} 


\title{
3.3. Lei de 26 de Julho de 1899
}

Esta lei de 1899 não apresenta nenhuma alteração significativa, sendo assim praticamente uma cópia do que já foi explicado, conservando inclusive o estatuto específico para as cidades de Lisboa e do Porto (sendo eleitos 3 deputados pela Invicta, $c f r$. artigo $40 .^{\circ}$ ). Passado algum tempo escrevia João de Meneses:

As leis de 96 e 99 foram duas leis essencialmente rotativas, que aproximaram e quase confundiram os dois grandes partidos históricos e custaram ao País, pelo predomínio que deram aos caciques, milhares de contos de réis ${ }^{40}$.

\subsection{Decreto de 8 de Agosto de 1901}

A já contextualizada "ignóbil porcaria" seria a lei vigente para as eleições que ocorreram a 6 de Outubro de 1901.

\begin{abstract}
Perante a situação criada pelas circunstâncias que sucintamente ficam expostas, entende o Governo que, respeitando-se a constituição do corpo eleitoral como está definida pela legislação vigente, é de instante necessidade alterar imediatamente o modo de eleger, substituindo-se à eleição por círculos plurinominais, com representação de minorias, e adoptando-se conjuntamente, sobre outros assuntos concernentes ao processo do recenseamento e ao da eleição, providências eficazes que assegurem a inscrição eleitoral a todos os cidadãos a que a lei reconhece o direito de votar e garantam a genuína e livre manifestação da vontade dos eleitores na escolha do representantes da nação. ${ }^{41}$
\end{abstract}

Como indica o seu preâmbulo, as principais alterações prendem-se com a divisão dos círculos, com o regime de escrutínio e com os mecanismos específicos da organização do processo eleitoral.

No que diz respeito ao regime censitário, a nova redação da lei seguirá o modelo já caracterizado pelas disposições que entraram em vigor com o Decreto de 28 de Março de 1895.

Com esta lei, visava-se um maior controlo dos actos relativos ao sufrágio por parte do Executivo. Foi essencial a eliminação dos círculos uninominais (cfr. artigos $400^{\circ}$ e seguintes), entrando-se numa nova era em que a reorganização dos círculos eleitorais contemplaria apenas círculos plurinominais, mais especificamente 22 no continente e 4 nas Ilhas Atlânticas (apesar de em alguns territórios coloniais vigorar ainda o regime uninominal).

As cidades de Lisboa e Porto eram, por sua vez, divididas em dois círculos eleitorais, que englobavam os concelhos rurais limítrofes. Simultaneamente, estabeleceu-se para todos os círculos o escrutínio de lista incompleta que admitia, em proporções variáveis, a representação de minorias. ${ }^{42}$

\footnotetext{
${ }^{40}$ ALMEIDA, P. Tavares de - “Comportamentos Eleitorais em Lisboa (1878-1910)”... p. 127.

${ }^{41}$ Preâmbulo do Decreto de 8 de Agosto de 1901.

${ }^{42}$ SOBRAL, José Manuel; ALMEIDA, Pedro Tavares de - "Caciquismo e poder político... p. 652.
} 
A representação das minorias seria para promover o assento parlamentar do Partido do sistema rotativista qua não fosse estar no Governo.

Em relação ao processo de controlo eleitoral, importa mencionar as transferências de competências para os servidores do Estado do trabalho executado pelas comissões de recenseamento.

Além de já termos observado que tais alterações iriam priorizar as vontades dos partidos tradicionais, visando afectar os católicos e, em grande foco, os franquistas, que eram o inimigo primordial a abater, a verdade é que o novo modo de escrutínio e a reorganização dos círculos eleitorais afectará os republicanos, sobretudo no Porto e demais zonas urbanas.

Os republicanos, principal agrupamento antidinástico, cuja força eleitoral se concentrava nas grandes cidades, viam-na enfraquecida pelos métodos típicos de gerrymandering mesmo obtendo maiorias nas assembleias urbanas, onde a politização do eleitorado era mais elevada e a ação fiscalizadora relativamente eficaz, esses resultados seriam asfixiados pelos votos da cintura rural. ${ }^{43}$

Podemos concluir que esta manobra política, realizada através de meios legislativos, alcançaria o sucesso pretendido e permitiria conservar as forças rotativistas no poder. Todavia, os presságios e os obstáculos que já enfrentavam em 1901 preconizavam que um breve sopro seria capaz de desmoronar o frágil sustento deste castelo de cartas. Em 1906, João Franco seria o símbolo do protesto no poder contra os partidos tradicionais e, em menos de uma década a contar desde a "ignóbil porcaria", o Republicanismo sairia vitorioso nas suas demandas.

\section{Eleições de 26 de Novembro de 1899}

\subsection{Motivos que levaram a anulação das mesmas}

De acordo com o artigo $95 .^{\circ}$ da Lei de 26 de Julho de 1899, “o tribunal de verificação de poderes tem por fim conhecer de todos os processos das eleições de deputados, julgando as reclamações ou protestos apresentantes, e, independentemente de reclamações ou protestos, declarando válidas ou nulas as mesmas eleições".

No seguimento desta norma, a 26 de Dezembro de 1899, o Tribunal de Verificação de Poderes, num acórdão em que o relator é o Juiz de Direito do Primeiro Distrito Criminal, Francisco Manoel de Almeida, determinará as eleições de Novembro de 1899 nulas. Era necessário repetir o acto eleitoral do círculo n. $^{\circ} 25$, onde haviam sido eleitos três deputados republicanos.

Após uma análise intensiva deste acórdão, em resultado do envio de diversos protestos que conduziram a audição de testemunhas, podemos considerar, sumariamente, que foram dez os motivos que levaram a esta decisão.

\footnotetext{
${ }^{43}$ Idem, ibidem. p. 652.
} 
Primeiro, observaram-se irregularidades no que toca às escolhas dos presidentes das assembleias eleitorais. Ao contrário do disposto no artigo $44 .^{\circ}$ e seguintes desta lei, nas assembleias primárias da Sé, Terço, Misericórdia, Santo Ildefonso, Congregados, Trindade e Padrão, os presidentes não foram nomeados pela respectiva comissão de recenseamento, nem escolhidos pela assembleia.

Segundo, na quase totalidade das assembleias não se apuraram os votos um a um, mas sim por maços de dez, vinte, vinte cinco e cinquenta, lendo-se apenas a primeira lista e contando-se o voto desta em detrimento das demais que não se liam (vide anexos, cfr. imagem 1). Reclamava-se não haver assim um sistema suficientemente transparente e conforme o ordenamento jurídico, como previsto no artigo $70 .^{\circ}$ e seguintes da lei que vigorava na época.

Terceiro, verificou-se ainda que na Assembleia dos Congregados, durante algum tempo, fez parte da mesa um indivíduo que não era eleitor, sendo posteriormente substituído por um eleitor indicado pelo respetivo presidente da mesa, nomeação que também não ocorre conforme os trâmites legais. Os restantes motivos foram os seguintes:

Em muitas assembleias votaram inúmeros indivíduos que não estavam recenseados, tomando os nomes de outros que o estavam e que não votaram, violando assim as disposições previstas nos artigos 61. ${ }^{\circ}$ e seguintes da Lei de 26 de Julho de 1899. A assembleia de Paranhos foi uma das várias em que tal se verificou, com a agravante de que foi inclusiva uma imposição da própria assembleia.

Por sua vez, na Assembleia da Trindade terem tomado parte na eleição da mesa indivíduos que não se encontravam recenseados. Mais, em algumas assembleias não se afixaram os editais que seriam necessários para uma boa e transparente organização do ato eleitoral; enquanto em outras não se cumpriram as duas horas de espera necessárias, deixando por isso de votar muitos eleitores. Em específico, na de Paranhos deixaram de votar por este motivo cerca de 700 eleitores. Aliás, nesta assembleia, houve, por vezes, momentos tumultuosos, não tendo sido acatadas as deliberações da mesa, uma vez que houve instrumentalização da força armada, o que levou à interrupção das operações eleitorais e, por estes motivos, foram efectuadas algumas prisões. Por fim, ainda na Assembleia de Paranhos continuou-se o apuramento depois de se ter posto o sol.

Face aos citados acidentes era imperativo que as eleições de Novembro de 1899 fossem anuladas no círculo 25 . 


\subsection{Resultados das eleições de 26 de Novembro de 1899}

$\mathrm{Na}$ elite portuense, os progressistas apresentavam assinável preponderância, motivo pelo qual a cidade se sedimentava como um bastião eleitoral deste partido. Todavia, face aos episódios de descontentamento para com o poder executivo já explicados, os progressistas não apoiaram a formação de nenhuma lista, motivo pelo qual oficialmente optaram por abster-se nas eleições neste círculo eleitoral.

Contudo, foi constituída uma lista de carácter apolítico e multipartidário por parte desta elite, que contou com a presença de António Pinto Magalhães (advogado), Manuel Duarte Pestana Silva (proprietário e lavrador do Douro) e José Gomes Silva (médico). Apesar de apresentar uma forte posição contra o Governo, José Luciano Castro acabará por demonstrar o seu apoio a esta lista, visto que era a única forma, na sua perspectiva, de impedir o avanço das facções anti-monárquicas, os republicanos.

Importa referir que, igualmente, os regeneradores preferiram não concorrer pelo círculo do Porto, optando por, inicialmente, não se intrometer nos conflitos políticos da cidade.

Devido ao descontentamento dos portuenses, surgiu uma lista republicana pelo Porto em 1899. Desde há vários anos que pairava uma crise no PRP, com cisões internas quanto à estratégia política a adoptar. Como protesto contra as leis eleitorais contextualizadas atrás, nem sequer tinham concorrido às eleições legislativas de 1895 e de 1897. Apesar de a Lei de 1899 não apresentar alterações significativas, as circunstâncias anormais permitiram dar um novo alento ao partido e à sua causa, o que resultou na sua candidatura. Percebemos isso através da análise do manifesto eleitoral do PRP, publicado a 20 de Novembro em A Pátria, que explorava, nomeadamente, as questões relacionadas com as desastrosas medidas de saúde pública do Governo.

O Partido Republicano considera-se, perante vós, eleitores, como capaz de interpretar completamente os vossos desgostos e ao mesmo tempo as vossas aspirações. Desgostos pelas violências praticadas contra a cidade e que tão largo abalo lhe produziram; aspirações por a implantação de um regime que rasgue à nacionalidade um horizonte de fortuna que não logra há séculos. ${ }^{44}$

Em boa verdade, a aguerrida defesa dos republicanos dos interesses da população do Porto nesta conjuntura, disseminada nomeadamente pela imprensa por si controlada, levará a uma vitória eleitoral dos republicanos no círculo eleitoral n. ${ }^{\circ} 25$.

\footnotetext{
${ }^{44}$ «Manifesto - Aos Cidadãos Portuenses», in A Pátria, nº 264, 20 de novembro e 1899, p. 2
} 
Tabela 1 - Resultados Finais das Eleições de 26 de Novembro de 1899

\begin{tabular}{|c|c|c|c|}
\hline \multicolumn{2}{|c|}{ Candidatos } & Total & Total (\%) \\
\hline \multirow{3}{*}{$\begin{array}{c}\text { Candidatos } \\
\text { monárquicos }\end{array}$} & António Pinto Magalhães & 2831 & $\mathbf{1 5 . 0 3 \%}$ \\
\cline { 2 - 4 } & José Gomes Silva & 3026 & $\mathbf{1 6 . 0 6 \%}$ \\
\cline { 2 - 4 } & Manuel Duarte Pestana Silva & 2653 & $\mathbf{1 4 . 0 8 \%}$ \\
\hline \multirow{2}{*}{$\begin{array}{c}\text { Candidatos } \\
\text { republicanos }\end{array}$} & Afonso Augusto Costa & 3383 & $\mathbf{1 7 . 9 6 \%}$ \\
\cline { 2 - 4 } & Francisco Xavier Esteves & 3342 & $\mathbf{1 7 . 7 4 \%}$ \\
\cline { 2 - 4 } & Paulo José Falcão & 3349 & $\mathbf{1 7 . 7 5 \%}$ \\
\hline
\end{tabular}

FONTE: AHP - Fundo do Tribunal de Verificação de Poderes, AEM, cx. 1637.

Verificámos que os três candidatos com um maior número de votos nas eleições de 26 de Novembro de 1899 são, assim, os representantes do PRP, pela seguinte ordem:

Afonso Augusto Costa (17.96\% dos votos); Paulo José Falcão (17.75\% dos votos); e Francisco Xavier Esteves (17.74\% dos votos).

No entanto, importa fazer uma análise mais detalhada destes resultados por bairro eleitoral.

Ao observar detalhadamente os resultados eleitorais referentes ao Bairro Oriental, podemos concluir que os candidatos do PRP foram os três mais votados, com enfoque para o candidato Afonso Augusto Costa.

Importa ressalvar os resultados de algumas assembleias: na assembleia da Sé, os três candidatos republicanos tiveram apenas mais 20 votos que os candidatos monárquicos (vide anexos, cfr. tabela 1); na freguesia do Bonfim, na assembleia do Padrão, os futuros “deputados da peste" obtiveram apenas mais oito votos que os seus adversários políticos; na freguesia de Campanhã, se na assembleia de São Roque os candidatos apoiados pelos partidos do sistema vencem por um total de três votos face aos republicanos, na de Campanhã, estes últimos vão perder de forma clara (vide anexos, cfr. tabela 2).

Em relação ao Bairro Ocidental, apesar das vitórias nos locais mais densamente povoados, como por exemplo, nas freguesias de Cedofeita e de Vitória, os republicanos apresentaram duras derrotas nas demais. Destacamos a massiva diferença de número de votos que ocorreu em Ramalde, 147 votos no total para os candidatos da lista republicana, contra os 1086 votos na outra lista (vide anexos, cfr. tabela 4).

A propósito, se apenas fossem contabilizados os resultados deste bairro eleitoral para a contagem final deste círculo, seria Afonso Costa o único candidato republicano a obter o mandato de deputado. 
Concluímos, assim, que o maior enraizamento dos ideais republicanos, na cidade do Porto, se verificou nas freguesias do Bairro Oriental, onde os seus candidatos obtiveram no total $58.85 \%$ dos votos, face ao $48.71 \%$ alcançados no Bairro Ocidental (vide anexos, cfr. tabela 3 e 6 ).

É de realçar que a diferença de votos que os candidatos republicanos apresentam entre si é mínima, muito menor que a dos deputados pró-Monarquia no Bairro Oriental, o que contribuiu para a clara vitória do PRP na globalidade das eleições.

\section{Eleições de 18 de Fevereiro de 1900}

Na repetição das eleições em Fevereiro de 1900, o Governo já apoiou oficialmente uma lista, composta por Abel Pereira Vale, o Conde Campo Belo (cientista) e António Vasconcelos (médico). Apresenta também uma nova atitude de campanha e propaganda eleitoral, demonstrando que o que está verdadeiramente em causa no Porto é a escolha de um regime político: monárquico ou republicano. Novamente perante a candidatura de apenas duas listas, todos aqueles que não almejassem uma República em Portugal deveriam demonstrar o seu apoio à lista apoiada pelo Governo.

Apesar de a situação epidemiológica apresentar progressivas melhorias, tendo inclusive o cordão sanitário sido levantado em Dezembro de 1900, bem como as leis que restringiam a liberdade de imprensa, os republicanos, mais uma vez com o apoio dos socialistas, voltarão a vencer as eleições.

Tabela 2 - Resultados Finais das Eleições de 18 de Fevereiro de 1899

\begin{tabular}{|c|c|c|c|}
\hline \multicolumn{2}{|c|}{ Candidatos } & Total & Total (\%) \\
\hline \multirow{3}{*}{$\begin{array}{c}\text { Candidatos } \\
\text { monárquicos }\end{array}$} & Abel Pereira do Vale & 3793 & $\mathbf{1 6 . 1 8 \%}$ \\
\cline { 2 - 4 } & António Vasconcelos & 3780 & $\mathbf{1 6 . 1 4 \%}$ \\
\cline { 2 - 4 } $\begin{array}{c}\text { Candidatos } \\
\text { republicanos }\end{array}$ & Conde Campo Belo & 3781 & $\mathbf{1 6 . 1 3 \%}$ \\
\cline { 2 - 4 } & Afonso Augusto Costa & 4026 & $\mathbf{1 7 . 1 8 \%}$ \\
\cline { 2 - 4 } & Francisco Xavier Esteves & 4028 & $\mathbf{1 7 . 1 9 \%}$ \\
\hline \multicolumn{2}{|c|}{ PONTE: AHP - Fundo do Tribunal de Verificação de Poderes, AEM, cx. 1989.} & $\mathbf{1 7 . 1 9 \%}$ \\
\hline
\end{tabular}

Além de assegurarem a vitória, o número absoluto de votos obtidos aumentou e conseguiram, desta vez, vencer em ambos os Bairros do círculo eleitoral n. ${ }^{\circ}$ 25. Contudo, a verdade é que a 18 de Fevereiro de 1900 a percentagem de votos na globalidade das eleições e a distância face aos candidatos monárquicos foi menor do que nas eleições do ano anterior.

Analisando os resultados por bairro eleitoral, verifica-se que se é verdade que os três deputados republicanos continuam a reunir mais votos no Bairro Oriental, também é verdade 
que, desta vez, a diferença é muito ténue face aos demais participantes nestas eleições. Isso deve-se sobretudo à esmagadora derrota sofrida nas freguesias de Campanhã e de Paranhos, onde se verifica também que a taxa de abstenção é menor do que nas restantes freguesias, possivelmente devido aos tumultos e impedimentos ocorridos nessas assembleias eleitorais nas eleições de Novembro de 1899, nomeadamente em Paranhos. Nas restantes freguesias, por norma, a percentagem da taxa de abstenção ronda, aproximadamente, os 50\%.

Em relação ao Bairro Ocidental, ao contrário do que verificámos nas eleições de 1899, os republicanos venceram as eleições no Bairro Ocidente a 18 de Fevereiro de 1900 e com uma margem bastante superior face aquilo que se verificou no Bairro Oriental.

Na repetição das eleições foram, assim, novamente eleitos os três "deputados da peste": Afonso Costa (17.18\% dos votos); Francisco Xavier Esteves e Paulo José Falcão (ambos com $17.19 \%$ dos votos).

Foram precisamente estes os três deputados que conseguiram assento parlamentar e que ficaram cognominados com o epíteto de "deputados da peste". Nesta senda, importa, brevemente, identificar o papel destes na Câmara dos Deputados.

A curta intervenção destes deputados do PRP na Câmara dos Deputados teve como um dos seus principais bastiões as duras críticas às medidas tomadas pelo Governo na crise sanitária vivida no Porto, entre as quais a implementação do cordão sanitário com consequências nefastas na economia da cidade. No entanto, bateram-se também por questões relacionadas com os impostos e a organização do sistema judicial, entre outras.

O que se fez foi desarrazoado e causou grandes danos. Desafio qualquer médico que the prove que os prejuízos causados pela doença, calculados segundo as boas regras da economia política, são maiores do que as produzidas pelas medidas do governo [...] a obrigação do governo era só ver se tratava de peste atenuada ou de peste intensiva; mas não fez isso e adoptou o sistema de barras, o mais apertado de todos e hoje universalmente condenado. ${ }^{45}$

A Câmara, estranhando que o Governo não tenha apresentado as contas da administração financeira das gerências da sua responsabilidade, e venha propor, em vez dor orçamento, um rol de gastos e imposições, sem conta nem equilíbrio, afirma que o país não só não pode com mais impostos além dos que sofre actualmente, como precisa de ponderação e restrição dos actualmente existentes [...] quando a opinião pública acentua cada vez mais a importância da questão mais grave que temos tido nos últimos tempos, o Governo trate a questão de dinheiro e se recuse a responder sobre uma questão de honra nacional. ${ }^{46}$

\footnotetext{
${ }^{45}$ Excerto de um discurso de Afonso Costa na Câmara dos Deputados, 15 de Março de 1900, Diário da Câmara dos Senhores Deputados, sessão n. ${ }^{\circ} 34$ de 15 de Março de 1900, p. 10.

${ }^{46}$ Excerto de uma moção de ordem de Paulo José Falcão na Câmara dos Deputados, 20 de Abril de 1900, Diário da Câmara dos Senhores Deputados, sessão n. ${ }^{\circ} 48$ de 20 de Abril de 1900, p. 7.
} 


\section{Eleições de 25 de Novembro de 1900 e de 6 de Outubro de 1901}

Em 25 de novembro de 1900, um ano após o pico do surto da peste bubónica, realizamse de novo eleições a nível nacional. O Governo volta a apresentar uma lista de candidatos para estas eleições. Contudo, apesar da activa participação dos deputados republicanos na Câmara dos Deputados, ainda que durante um curto período, estes começam a perder destaque na imprensa e junto das elites portuenses que, apesar do seu descontentamento no ano anterior, continuam a preferir a estabilidade que o regime vigente lhes oferecia.

Tabela 3 - Resultados Finais das Eleições de 25 de Novembro de 1900

\begin{tabular}{|c|c|c|c|}
\hline \multicolumn{2}{|c|}{ Candidatos } & Total & Total (\%) \\
\hline \multirow{3}{*}{$\begin{array}{c}\text { Candidatos } \\
\text { monárquicos }\end{array}$} & Clemente Pinto & $\mathbf{7 3 7 3}$ & $\mathbf{2 1 . 5 1 \%}$ \\
\cline { 2 - 4 } & Francisco Joaquim Fernandes & $\mathbf{7 5 2 2}$ & $\mathbf{2 1 . 9 5 \%}$ \\
\cline { 2 - 4 } & Souza Avides & $\mathbf{7 3 3 3}$ & $\mathbf{2 1 . 3 9 \%}$ \\
\hline \multirow{2}{*}{$\begin{array}{c}\text { Candidatos } \\
\text { republicanos }\end{array}$} & Afonso Augusto Costa & $\mathbf{4 2 0 2}$ & $\mathbf{1 2 . 2 6 \%}$ \\
\cline { 2 - 4 } & Francisco Xavier Esteves & $\mathbf{3 9 0 1}$ & $\mathbf{1 1 . 3 8 \%}$ \\
\cline { 2 - 4 } & \multicolumn{2}{|c|}{ Paulo José Falcão } & $\mathbf{3 9 4 4}$ \\
\hline
\end{tabular}

Nestas eleições, apesar de o número absoluto de votos nos candidatos do PRP não ter alterado significativamente face às eleições de Fevereiro de 1900, uma maior participação eleitoral no sufrágio teve como consequência a derrota dos republicanos, dado que os candidatos monárquicos já seriam pertencentes aos partidos do sistema.

Destacamos, portanto, a considerável derrota dos republicanos, que em termos relativos, não conseguiram obter mais do que $35.15 \%$ dos votos na globalidade.

No Bairro Oriental, os republicanos conseguem vencer uma vez mais na freguesia do Bonfim, devido às vitórias nas assembleias do Bonfim e da Boavista. Ainda neste Bairro venceram as eleições na freguesia de Santo Ildefonso, com vitória assegurada em todas as suas assembleias de voto. De realçar ainda a vitória na assembleia da Misericórdia, na freguesia da Sé. Verificamos, uma vez mais, uma pesada derrota em Paranhos, como tem sido padrão ao longo da análise destes dados eleitorais.

Por fim, no Bairro Ocidental, apenas venceram nas Assembleias de Cedofeita e da Lapa. Foi também neste bairro eleitoral que obtiveram os seus piores resultados, como acontecera anteriormente, na assembleia de Ramalde.

Com a situação pandémica já controlada, nestas eleições ambos os partidos tradicionais do sistema apresentaram listas de candidatura. 
Tabela 4 - Resultados Finais das Eleições de 6 de Outubro de 1901

\begin{tabular}{|c|c|c|c|}
\hline \multicolumn{2}{|r|}{ Candidatos } & Total & Total (\%) \\
\hline \multirow{10}{*}{$\begin{array}{l}\text { Candidatos } \\
\text { monárquicos }\end{array}$} & Artur Eduardo Brandão & 2220 & $6,02 \%$ \\
\hline & Avelino Monteiro & 2241 & $6,07 \%$ \\
\hline & Francisco José Patrício & 2239 & $6,07 \%$ \\
\hline & José de Cunha Lima & 2135 & $5,79 \%$ \\
\hline & Souza Avides & 2220 & $6,02 \%$ \\
\hline & Clemente Pinto & 2861 & $7,75 \%$ \\
\hline & Carlos Alberto Soares Cardoso & 2856 & $7,74 \%$ \\
\hline & Cristóvão Magalhães Sepúlveda & 2853 & $7,73 \%$ \\
\hline & António de Barbosa Mendonça & 2840 & $7,70 \%$ \\
\hline & Alberto Navarro & 2904 & $7,87 \%$ \\
\hline \multirow{5}{*}{$\begin{array}{l}\text { Candidatos } \\
\text { republicanos }\end{array}$} & Afonso Augusto Costa & 2349 & $6,37 \%$ \\
\hline & Francisco Xavier Esteves & 2299 & $6,23 \%$ \\
\hline & Paulo José Falcão & 2285 & $6,19 \%$ \\
\hline & António José de Almeida & 2301 & $6,24 \%$ \\
\hline & Joaquim Silva Albuquerque & 2285 & $6,19 \%$ \\
\hline
\end{tabular}

FONTE: AHP - Fundo do Tribunal de Verificação de Poderes, AEM, cx. 2063 e cx. 2064C.

Em relação às eleições de 6 de Outubro de 1901, importa realçar que os resultados do círculo eleitoral, com o novo desenho do método típico de gerrymandering, não seriam apenas os provenientes do concelho do Porto. Mais, enquanto os candidatos republicanos se apresentaram a eleições, quer no Bairro Ocidental, quer no Bairro Oriental, já os candidatos monárquicos dividiram-se, uma lista para cada um dos bairros.

Observa-se, portanto, que o número absoluto de votos nos candidatos do PRP foi consideravelmente menor face às demais eleições em apreço, visto que certos candidatos submetidos a escrutínio em apenas um dos bairros conseguiram obter uma percentagem de votos superior, quando comparada com estes.

Nestas eleições não nos é possível indicar os candidatos que venceram neste círculo eleitoral, uma vez que a nossa investigação se debruçou exclusivamente nos resultados do concelho do Porto. No entanto, importa mencionar que no Bairro Ocidental, os republicanos não venceram em nenhuma freguesia. Já no Bairro Oriental, local onde os dados desta investigação têm demonstrado que o PRP apresentava um maior predomínio, este partido venceu na freguesia de Santo Ildefonso, nas suas três assembleias de voto, e na freguesia de Bonfim, com 
vitória em todas as assembleias, à excepção da assembleia do Padrão. Conquanto, estas vitórias não foram suficientes para alcançar uma vitória neste bairro na sua generalidade, devido à pesada derrota nas assembleias da Misericórdia e de São Roque, onde não obtiveram nenhum voto.

Não obstante, importa inferir destes resultados que os candidatos republicanos, entre si, não apresentam uma diferença substancial de votos, o que demonstra que o seu eleitorado é composto por cidadãos que defendem e acreditam nos ideais políticos defendidos pelo Partido Republicano, ao invés de ser um eleitorado atraído apenas por um elemento dominante desse mesmo partido.

\section{Conclusão}

O período em análise demonstra a instabilidade político-social que assolava o território português à época, não só pelos curtos governos e pelas estratégicas alianças e válvulas de escape protagonizadas nos bastidores da cena política, mas também pelo carácter de debilidade das infraestruturas no combate a uma situação de autêntica calamidade de saúde pública.

Nas ruas do Porto sentia-se a presença da mortífera peste bubónica que confinava a população à habitação e constrangia qualquer tipo de actividade mercantil e de desenvolvimento económico, devido às as medidas restritivas impostas. Uma cidade sem transeuntes que, a cada dia que passava, testemunhava o aumento de revolta para com o poder executivo, que se via numa situação de manifesto descrédito.

Esta investigação permitiu compreender as diversas alterações na legislação eleitoral que vigorou na época, sendo que o denominador comum para as suas mutações foi sempre a priorização das vontades do partido no poder e da garantia do sistema de forma monárquica. Podemos também ainda concluir que em relação ao Decreto de 8 de Agosto de 1901, que visou afectar os católicos e, especialmente, os franquistas, inimigos primordiais a abater, este teve um duplo sucesso - cumpriu os efeitos pretendidos e, uma vez que, adicionalmente no Porto e demais zonas urbanas, o novo modo de escrutínio e a reorganização dos círculos eleitorais afectaram os republicanos, travou, também, o seu crescimento.

Em relação à forma como as. Eleições decorreram, ao contrário das contestações dos republicanos, conforme as normas da Lei Eleitoral em vigor à época, as eleições de 26 de Novembro de 1899 foram devidamente anuladas no círculo eleitoral do Porto.

Mas o principal destaque da nossa investigação, é a conclusão de que a eleição dos três deputados republicanos nas eleições de 26 de Novembro de 1899 e na sua repetição de 18 de Fevereiro de 1900 teve como principal causa um motivo conjuntural: a crise sanitária que se vivia na cidade. Desta forma e como podemos constatar pelos resultados nas subsequentes 
eleições, os ideais republicanos não estavam enraizados na sociedade. Apesar de uma maior estabilidade dos resultados dos republicanos no Bairro Oriental, após as eleições de 18 de Fevereiro de 1900, nem junto destas assembleias de voto conseguiram a almejada vitória eleitoral.

A verdade é que já contextualizada, a situação precária sentida no Porto gerou, não somente junto da classe popular, mas também das elites, um forte descontentamento, disseminado pela imprensa.

Mormente, estes republicanos tiveram um papel activo no seu curto período de intervenção na Câmara dos Deputados, episódio este que se mostrou fulcral para a angariação de um maior destaque na opinião pública.

Reitera-se que este estudo centrou-se no comportamento eleitoral verificado no Porto, com um enfoque no Partido Republicano Português, e que para se compreender o enraizamento do republicanismo na sociedade portuguesa, serão necessários estudos semelhantes sobre os resultados eleitorais deste partido em diferentes zonas geográficas.

Por fim, acreditamos que esta é uma análise que introduz uma premissa para um estudo mais aprofundado, numa temática plural, possibilitando estudar inúmeros aspectos, com base em diferentes variáveis, não só em relação à cidade do Porto e ao panorama político nacional, mas nomeadamente ao estado do PRP nos anos finais da sua fase de propaganda.

\section{Fontes}

\section{Fontes do Arquivo Histórico Parlamentar}

AHP - Fundo do Tribunal de Verificação de Poderes, AEM, cx. 1637 (referentes à eleição de 26 de Novembro de 1899);

AHP - Fundo do Tribunal de Verificação de Poderes, AEM, cx. 1989 e cx. 1989A (referentes à eleição de 18 de Fevereiro de 1900);

AHP - Fundo do Tribunal de Verificação de Poderes, AEM, cx. 2028 e cx. 2028A (referentes à eleição de 25 de Novembro de 1900);

AHP - Fundo do Tribunal de Verificação de Poderes, AEM, cx. 2063 e cx. 2064C (referentes à eleição de 6 de Outubro de 1901).

\section{Debates Parlamentares}

Diário da Câmara dos Deputados (Março-Junho de 1900).

\section{Fontes hemerográficas}

A Pátria, Lisboa, Setembro de 1899 a Fevereiro de 1900; Outubro-Novembro 1900; JunhoOutubro 1901. 


\section{Fontes Legislativas}

ALMEIDA, P. Tavares de - Legislação Eleitoral Portuguesa (1820-1926). Lisboa: Imprensa Nacional - Casa da Moeda, 1998.

\section{Documentação epistolar}

ALMEIDA, P. Tavares de - Nos Bastidores das Eleições de 1881 e 1901: Correspondência política de José Luciano de Castro. Lisboa: Livros Horizonte, 2001.

\section{Bibliografia}

ALMEIDA, P. Tavares de - "Comportamentos Eleitorais em Lisboa (1878-1910)". Análise Social. [Em Linha] Vol. XXI, n. ${ }^{\circ} 85$ (1985), pp. 111-152. Disponível em WWW:URL: $<$ http://analisesocial.ics.ul.pt/documentos/1223476625X7hRU7op8Au42WX1.pdf $>$.

_- Eleições e Caciquismo no Portugal Oitocentista, 1868-1890. Lisboa: Difel, 1991.

CATROGA, Fernando - O Republicanismo em Portugal: da formação ao 5 de Outubro de 1910. 3. a ed. Lisboa: Casa das Letras, 2010.

- - "O Republicanismo Português (Cultura, História e Política)". Revista da Faculdade de Letras - História. [Em Linha] Porto. III Série, vol. 11 (2010) pp. 94-119. Disponível em WWW:URL: $<$ https://ler.letras.up.pt/uploads/ficheiros/9008.pdf $>$.

MÓNICA, Maria Filomena - "As Reformas Eleitorais no constitucionalismo monárquico, 1852-1910”. Análise Social. [Em Linha] Vol. XXXI, n. ${ }^{\circ} 139$ (1996), pp. 1039-1084. Disponível em WWW:URL:< http://analisesocial.ics.ul.pt/documentos/1223396410E4cIS9bh9Gh98WL9.pdf>.

PONTES, David - O cerco da peste no Porto: cidade, imprensa, saúde pública na crise sanitária de 1899. [Em Linha] Porto: Dissertação apresentada para a obtenção do grau de Mestre em História na Faculdade de Letras da Universidade do Porto. Disponível em WWW:URL: $<$ https://sigarra.up.pt/fcup/pt/pub geral.pub view?pi pub base $\mathrm{id}=28279>$.

RAMOS, Rui - A Segunda Fundação 1890-1926, Vol. 6 In J. Mattoso (org.), "História de Portugal", Lisboa, Editorial Estampa, 2001, pp. 217-222.

SOBRAL, José Manuel; ALMEIDA, Pedro Tavares de - "Caciquismo e poder político. Reflexões em torno das eleições de 1901". Análise Social. [Em Linha] Vol. XVIII, n. ${ }^{\text {os }}$ 72, 73, 74. (1982), pp. 649-671. Disponível em WWW:URL:< http://hdl.handle.net/10362/9128>. 


\section{Anexos}

Tabela 1 - Resultados das freguesias da Sé e de Santo Ildefonso nas Eleições de 26 de Novembro 1899

\begin{tabular}{|c|c|c|c|c|c|c|c|c|c|}
\hline \multirow{2}{*}{\multicolumn{2}{|c|}{ Candidatos }} & \multicolumn{4}{|c|}{ Freguesia da Sé } & \multicolumn{4}{|c|}{ Freguesia de Santo Ildefonso } \\
\hline & & $\begin{array}{c}\text { Assembleia } \\
\text { da Sé }\end{array}$ & $\begin{array}{c}\text { Assembleia } \\
\text { do Terço }\end{array}$ & $\begin{array}{l}\text { Assembleia da } \\
\text { Misericórdia }\end{array}$ & Total & $\begin{array}{l}\text { Assembleia de } \\
\text { Santo Ildefonso }\end{array}$ & $\begin{array}{c}\text { Assembleia } \\
\text { Congregados }\end{array}$ & $\begin{array}{c}\text { Assembleia } \\
\text { Trindade }\end{array}$ & Total \\
\hline \multirow{3}{*}{$\begin{array}{l}\text { Candidatos } \\
\text { monárquicos }\end{array}$} & António Pinto Magalhães & 43 & 97 & 112 & 252 & 115 & 131 & 90 & 336 \\
\hline & José Gomes Silva & 47 & 110 & 124 & 281 & 125 & 154 & 101 & 380 \\
\hline & Manuel Duarte Pestana Silva & 43 & 88 & 102 & 233 & 109 & 117 & 82 & 308 \\
\hline \multirow{3}{*}{$\begin{array}{l}\text { Candidatos } \\
\text { republicanos }\end{array}$} & Afonso Augusto Costa & 51 & 141 & 211 & 403 & 231 & 287 & 127 & 645 \\
\hline & Francisco Xavier Esteves & 52 & 130 & 214 & 396 & 217 & 277 & 124 & 618 \\
\hline & Paulo José Falcão & 50 & 127 & 213 & 390 & 230 & 285 & 121 & 636 \\
\hline
\end{tabular}

FONTE: AHP - Fundo do Tribunal de Verificação de Poderes, AEM, cx. 1637.

Tabela 2 - Resultados das freguesias de Bonfim, Campanhã e Paranhos nas Eleições de 26 de Novembro de 1899

\begin{tabular}{|c|c|c|c|c|c|c|c|c|c|}
\hline & \multirow[b]{2}{*}{ Candidatos } & \multicolumn{4}{|c|}{ Freguesia do Bonfim } & \multicolumn{3}{|c|}{ Freguesia de Campanhã } & \multirow{2}{*}{$\begin{array}{c}\begin{array}{c}\text { Freguesia de } \\
\text { Paranhos }\end{array} \\
\text { Assembleia de } \\
\text { Paranhos }\end{array}$} \\
\hline & & $\begin{array}{l}\text { Assembleia } \\
\text { do Bonfim }\end{array}$ & $\begin{array}{l}\text { Assembleia } \\
\text { do Padrão }\end{array}$ & $\begin{array}{c}\text { Assembleia da } \\
\text { Boavista }\end{array}$ & Total & Assembleia de & Assembleia de & Total & \\
\hline \multirow{3}{*}{$\begin{array}{l}\text { Candidatos } \\
\text { monárquicos }\end{array}$} & António Pinto Magalhães & 81 & 92 & 106 & 277 & 107 & 71 & 178 & 134 \\
\hline & José Gomes Silva & 89 & 96 & 120 & 310 & 107 & 72 & 179 & 136 \\
\hline & Manuel Duarte Pestana Silva & 71 & 92 & 101 & 254 & 107 & 66 & 173 & 117 \\
\hline \multirow{3}{*}{$\begin{array}{l}\text { Candidatos } \\
\text { republicanos }\end{array}$} & Afonso Augusto Costa & 170 & 96 & 155 & 452 & 60 & 69 & 129 & 162 \\
\hline & Francisco Xavier Esteves & 166 & 96 & 148 & 438 & 60 & 70 & 130 & 169 \\
\hline & Paulo José Falcão & 166 & 96 & 151 & 438 & 60 & 73 & 133 & 160 \\
\hline
\end{tabular}

FONTE: AHP - Fundo do Tribunal de Verificação de Poderes, AEM, cx. 1637.

Tabela 3 - Resultados Finais do Bairro Oriental nas Eleições de 26 de Novembro de 1899

\begin{tabular}{|c|c|c|c|}
\hline \multicolumn{2}{|c|}{ Candidatos } & Total & Total (\%) \\
\hline \multirow{3}{*}{$\begin{array}{c}\text { Candidatos } \\
\text { monárquicos }\end{array}$} & António Pinto Magalhães & 1179 & $13.31 \%$ \\
\cline { 2 - 4 } & José Gomes Silva & 1281 & $\mathbf{1 4 . 4 6 \%}$ \\
\cline { 2 - 4 } & Manuel Duarte Pestana Silva & 1095 & $12.36 \%$ \\
\hline \multirow{2}{*}{$\begin{array}{c}\text { Candidatos } \\
\text { republicanos }\end{array}$} & Afonso Augusto Costa & 1760 & $19.86 \%$ \\
\cline { 2 - 4 } & Francisco Xavier Esteves & 1723 & $19.44 \%$ \\
\cline { 2 - 4 } & Paulo José Falcão & 1732 & $19.55 \%$ \\
\hline
\end{tabular}

FONTE: AHP - Fundo do Tribunal de Verificação de Poderes, AEM, cx. 1637.

Tabela 4 - Resultados das freguesias de São Nicolau, Foz, Cedofeita, Ramalde nas Eleições de 26 de

Novembro de 1899

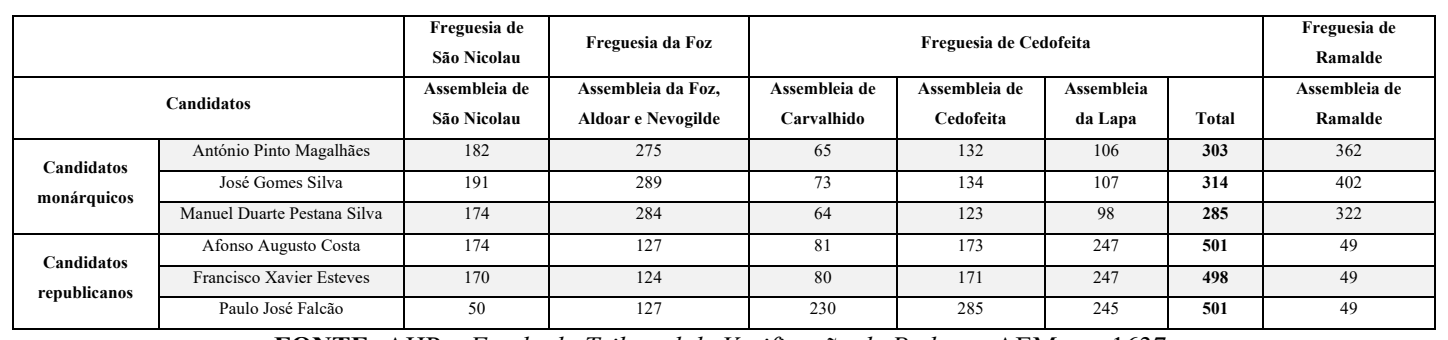

FONTE: AHP - Fundo do Tribunal de Verificação de Poderes, AEM, cx. 1637.

Tabela 5 - Resultados das freguesias de Massarelos, Lordelo, Vitória, Carvalhido e Miragaia nas Eleições de 26 de Novembro de 1899

\begin{tabular}{|c|c|c|c|c|c|c|c|c|}
\hline \multirow{2}{*}{\multicolumn{2}{|c|}{ Candidatos }} & \multirow{2}{*}{$\begin{array}{c}\begin{array}{c}\text { Freguesia de } \\
\text { Massarelos }\end{array} \\
\text { Assembleia de } \\
\text { Massarelos }\end{array}$} & \multirow{2}{*}{$\begin{array}{c}\begin{array}{c}\text { Freguesia de } \\
\text { Lordelo }\end{array} \\
\begin{array}{c}\text { Assembleia do } \\
\text { Lordelo }\end{array}\end{array}$} & \multicolumn{3}{|c|}{ Freguesia da Vitória } & \multirow{2}{*}{\begin{tabular}{|c|}
$\begin{array}{c}\text { Freguesia do } \\
\text { Carvalhido }\end{array}$ \\
Assembleia do \\
Carvalhido
\end{tabular}} & \multirow{2}{*}{$\begin{array}{c}\begin{array}{c}\text { Freguesia de } \\
\text { Miragaia }\end{array} \\
\text { Assembleia de } \\
\text { Miragaia }\end{array}$} \\
\hline & & & & $\begin{array}{c}\text { Assembleia da } \\
\text { Vitória }\end{array}$ & $\begin{array}{l}\text { Assembleia do } \\
\text { Carmo }\end{array}$ & Total & & \\
\hline \multirow{3}{*}{$\begin{array}{l}\text { Candidatos } \\
\text { monárquicos }\end{array}$} & António Pinto Magalhães & 122 & 159 & 59 & 97 & 156 & 65 & 93 \\
\hline & José Gomes Silva & 125 & 161 & 62 & 103 & 165 & 73 & 98 \\
\hline & Manuel Duarte Pestana Silva & 107 & 157 & 56 & 87 & 143 & 64 & 86 \\
\hline \multirow{3}{*}{$\begin{array}{l}\text { Candidatos } \\
\text { republicanos }\end{array}$} & Afonso Augusto Costa & 92 & 111 & 300 & 183 & 483 & 81 & 86 \\
\hline & Francisco Xavier Esteves & 110 & 114 & 297 & 173 & 470 & 80 & 84 \\
\hline & Paulo José Falcão & 96 & 112 & 300 & 179 & 479 & 80 & 85 \\
\hline
\end{tabular}

FONTE: AHP - Fundo do Tribunal de Verificação de Poderes, AEM, cx. 1637. 
Tabela 6 - Resultados Finais do Bairro Oriental nas Eleições de 26 de Novembro de 1899

\begin{tabular}{|c|c|c|c|}
\hline \multicolumn{2}{|c|}{ Candidatos } & Total & Total (\%) \\
\hline \multirow{3}{*}{$\begin{array}{c}\text { Candidatos } \\
\text { monárquicos }\end{array}$} & António Pinto Magalhães & 1652 & $\mathbf{1 6 . 5 6 \%}$ \\
\cline { 2 - 4 } & José Gomes Silva & 1745 & $\mathbf{1 7 . 4 9 \%}$ \\
\cline { 2 - 4 } & Manuel Duarte Pestana Silva & 1558 & $\mathbf{1 5 . 6 1 \%}$ \\
\hline \multirow{2}{*}{$\begin{array}{c}\text { Candidatos } \\
\text { republicanos }\end{array}$} & Afonso Augusto Costa & 1623 & $\mathbf{1 6 . 2 7 \%}$ \\
\cline { 2 - 4 } & Francisco Xavier Esteves & 1619 & $\mathbf{1 6 . 2 3} \%$ \\
\cline { 2 - 4 } & Paulo José Falcão & 1617 & $\mathbf{1 6 . 2 1 \%}$ \\
\hline
\end{tabular}

FONTE: AHP - Fundo do Tribunal de Verificação de Poderes, AEM, cx. 1637.

Tabela 7 - Resultados das freguesias da Sé e de Santo Ildefonso nas Eleições de 18 de Fevereiro de 1900

\begin{tabular}{|c|c|c|c|c|c|c|c|c|c|}
\hline \multirow{2}{*}{\multicolumn{2}{|c|}{ Candidatos }} & \multicolumn{4}{|c|}{ Freguesia da Sé } & \multicolumn{4}{|c|}{ Freguesia de Santo Ildefonso } \\
\hline & & \multirow{2}{*}{$\begin{array}{c}\begin{array}{c}\text { Assemblei } \\
\text { a da Sé }\end{array} \\
66\end{array}$} & \multirow{2}{*}{$\begin{array}{c}\begin{array}{c}\text { Assembleia } \\
\text { do Terço }\end{array} \\
98\end{array}$} & \multirow{2}{*}{$\begin{array}{c}\begin{array}{c}\text { Assembleia da } \\
\text { Misericórdia }\end{array} \\
58\end{array}$} & \multirow{2}{*}{\begin{tabular}{c|} 
Total \\
222 \\
\end{tabular}} & \multirow{2}{*}{$\begin{array}{c}\begin{array}{c}\text { Assembleia } \\
\text { de Santo } \\
\text { Ildefonso }\end{array} \\
78\end{array}$} & \multirow{2}{*}{$\begin{array}{c}\text { Assembleia } \\
\text { Congregados }\end{array}$} & \multirow{2}{*}{$\begin{array}{c}\begin{array}{c}\text { Assembleia } \\
\text { Trindade }\end{array} \\
110\end{array}$} & \multirow{2}{*}{$\begin{array}{c}\text { Total } \\
196 \\
\end{array}$} \\
\hline & Abel Pereira do Vale & & & & & & & & \\
\hline monárauicos & António Vasconcelos & 66 & 96 & 56 & 218 & 77 & 83 & 110 & 196 \\
\hline & Conde Campo Belo & 67 & 98 & 58 & 223 & 76 & 82 & 109 & 194 \\
\hline \multirow{3}{*}{$\begin{array}{l}\text { Candidatos } \\
\text { republicanos }\end{array}$} & Afonso Augusto Costa & 82 & 191 & 268 & 541 & 380 & 183 & 198 & 889 \\
\hline & Francisco Xavier Esteves & 82 & 191 & 270 & 543 & 378 & 183 & 198 & 888 \\
\hline & Paulo José Falcão & 83 & 191 & 268 & 542 & 378 & 183 & 199 & 887 \\
\hline \multicolumn{2}{|c|}{ Lista de entradas } & 150 & 290 & 328 & 768 & 363 & 462 & 268 & 1093 \\
\hline \multicolumn{2}{|c|}{ Listas inutilizadas } & 1 & 1 & 2 & 4 & 1 & & & 1 \\
\hline \multicolumn{2}{|c|}{ Número de cidadãos recenseados } & 273 & 607 & 605 & 1485 & 670 & 742 & 548 & 1980 \\
\hline \multicolumn{2}{|c|}{ Número absoluto de abstenções } & 122 & 316 & 275 & 713 & 306 & 280 & 280 & 888 \\
\hline \multicolumn{2}{|c|}{ Percentagem da abstenção } & $44.68 \%$ & $52.06 \%$ & $45.45 \%$ & $48.01 \%$ & $45.67 \%$ & $37.84 \%$ & $51.09 \%$ & $44.85 \%$ \\
\hline
\end{tabular}

FONTE: AHP - Fundo do Tribunal de Verificação de Poderes, AEM, cx. 1989.

Tabela 8 - Resultados das freguesias de Bonfim e de Campanhã nas Eleições de 18 de Fevereiro de 1900

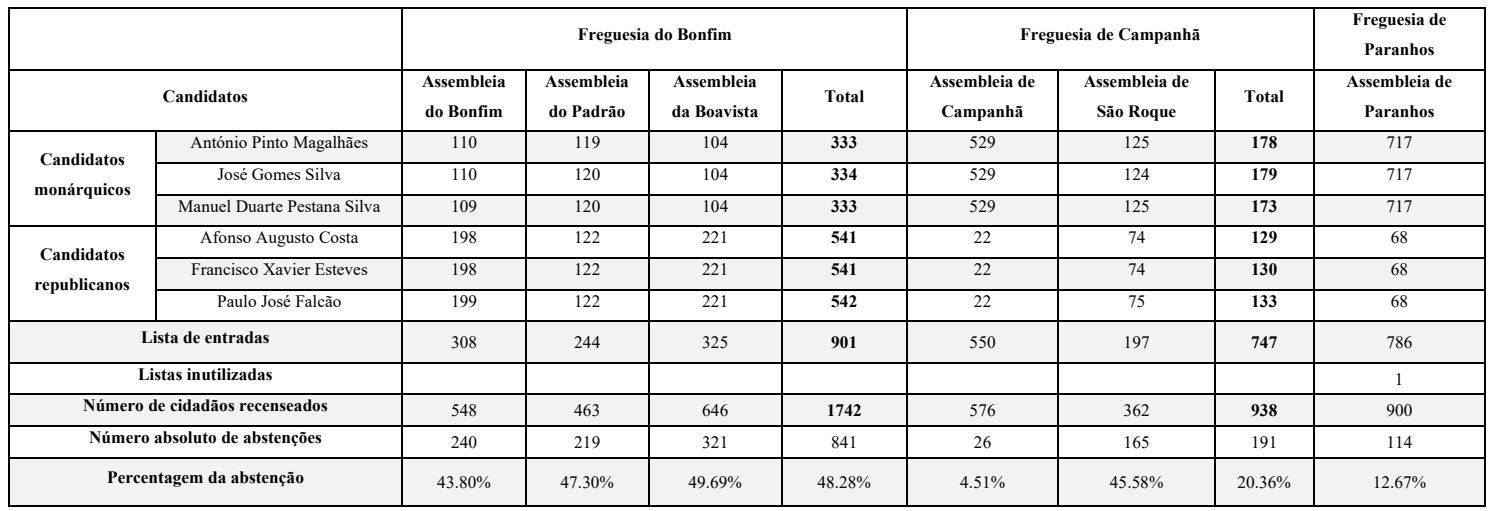

FONTE: AHP - Fundo do Tribunal de Verificação de Poderes, AEM, cx. 1989.

Tabela 9 - Resultados Finais do Bairro Oriental nas Eleições de 18 de Fevereiro de 1900

\begin{tabular}{|c|c|c|c|}
\hline \multicolumn{2}{|c|}{ Candidatos } & Total & Total (\%) \\
\hline \multirow{3}{*}{$\begin{array}{c}\text { Candidatos } \\
\text { monárquicos }\end{array}$} & Abel Pereira do Vale & 2122 & 16.62 \\
\cline { 2 - 4 } & António Vasconcelos & 2118 & 16.59 \\
\cline { 2 - 4 } & Conde Campo Belo & 2121 & 16.61 \\
\hline \multirow{3}{*}{$\begin{array}{c}\text { Candidatos } \\
\text { republicanos }\end{array}$} & Afonso Augusto Costa & 2135 & 16.72 \\
\cline { 2 - 4 } & Francisco Xavier Esteves & 2136 & 16.73 \\
\cline { 2 - 4 } & Paulo José Falcão & 2136 & 16.73 \\
\hline
\end{tabular}

FONTE: AHP - Fundo do Tribunal de Verificação de Poderes, AEM, cx. 1989. 
Tabela 10 - Resultados das freguesias de São Nicolau, Foz, Cedofeita e Ramalde nas Eleições de 18 de Fevereiro de 1900

\begin{tabular}{|c|c|c|c|c|c|c|c|c|}
\hline \multirow{2}{*}{\multicolumn{2}{|c|}{ Candidatos }} & \multirow{2}{*}{$\begin{array}{c}\begin{array}{c}\text { Freguesia de São } \\
\text { Nicolau }\end{array} \\
\text { Assembleia de } \\
\text { São Nicolau }\end{array}$} & \multirow{2}{*}{$\begin{array}{l}\text { Freguesia da Foz } \\
\text { Assembleia da Foz, } \\
\text { Aldoar e Nevogilde }\end{array}$} & \multicolumn{4}{|c|}{ Freguesia de Cedofeita } & \multirow{2}{*}{$\begin{array}{c}\begin{array}{c}\text { Freguesia de } \\
\text { Ramalde }\end{array} \\
\text { Assembleia de } \\
\text { Ramalde }\end{array}$} \\
\hline & & & & $\begin{array}{l}\text { Assembleia de } \\
\text { Carvalhido }\end{array}$ & $\begin{array}{l}\text { Assembleia de } \\
\text { Cedofeita }\end{array}$ & $\begin{array}{c}\text { Assembleia } \\
\text { da Lapa }\end{array}$ & Total & \\
\hline \multirow{3}{*}{$\begin{array}{l}\text { Candidatos } \\
\text { monárquicos }\end{array}$} & Abel Pereira do Vale & 75 & 271 & 88 & 77 & 104 & 615 & 541 \\
\hline & António Vasconcelos & 74 & 270 & 86 & 77 & 103 & 610 & 541 \\
\hline & Conde Campo Belo & 75 & 270 & 88 & 76 & 104 & 613 & 541 \\
\hline \multirow{3}{*}{$\begin{array}{l}\text { Candidatos } \\
\text { republicanos }\end{array}$} & Afonso Augusto Costa & 271 & 189 & 103 & 246 & 276 & 1085 & 17 \\
\hline & Francisco Xavier Esteves & 272 & 190 & 104 & 246 & 276 & 1088 & 17 \\
\hline & Paulo José Falcão & 273 & 189 & 103 & 246 & 277 & 1088 & 17 \\
\hline \multicolumn{2}{|c|}{ Lista de entradas } & 348 & 461 & 195 & 327 & 382 & 1713 & 558 \\
\hline \multicolumn{2}{|c|}{ Listas inutilizadas } & - & 1 & 3 & - & 2 & 6 & - \\
\hline \multicolumn{2}{|c|}{ Número de cidadãos recenseados } & 639 & 778 & 362 & 796 & 843 & 2001 & 599 \\
\hline \multicolumn{2}{|c|}{ Número absoluto de abstenções } & 291 & 316 & 164 & 469 & 459 & 1092 & 41 \\
\hline \multicolumn{2}{|c|}{ Percentagem da abstenção } & $45.54 \%$ & $40.62 \%$ & $45.30 \%$ & 58,92 & $54.45 \%$ & $49.61 \%$ & $6.85 \%$ \\
\hline
\end{tabular}

FONTE: AHP - Fundo do Tribunal de Verificação de Poderes, AEM, cx. 1989A.

Tabela 11 - Resultados das freguesias de Massarelos, Lordelo, Vitória, Carvalhido e Miragaia nas Eleições de 18 de Fevereiro de 1900

\begin{tabular}{|c|c|c|c|c|c|c|c|c|}
\hline & & $\begin{array}{c}\text { Freguesia de } \\
\text { Massarelos }\end{array}$ & $\begin{array}{c}\text { Freguesia de } \\
\text { Lordelo }\end{array}$ & & Iesia da Vitória & & $\begin{array}{c}\text { Freguesia do } \\
\text { Carvalhido }\end{array}$ & $\begin{array}{c}\text { Freguesia de } \\
\text { Miragaia }\end{array}$ \\
\hline \multicolumn{2}{|c|}{ Candidatos } & $\begin{array}{c}\text { Assembleia de } \\
\text { Massarelos }\end{array}$ & $\begin{array}{l}\text { Assembleia do } \\
\text { Lordelo }\end{array}$ & $\begin{array}{c}\text { Assembleia da } \\
\text { Vitória }\end{array}$ & $\begin{array}{c}\text { Assembleia do } \\
\text { Carmo }\end{array}$ & Total & $\begin{array}{c}\text { Assembleia do } \\
\text { Carvalhido }\end{array}$ & $\begin{array}{c}\text { Assembleia de } \\
\text { Miragaia }\end{array}$ \\
\hline \multirow{3}{*}{$\begin{array}{l}\text { Candidatos } \\
\text { monárquicos }\end{array}$} & Abel Pereira do Vale & 141 & 128 & 91 & 61 & 152 & 88 & 94 \\
\hline & António Vasconcelos & 140 & 128 & 90 & 59 & 149 & 86 & 94 \\
\hline & Conde Campo Belo & 140 & 127 & 90 & 58 & 148 & 88 & 91 \\
\hline \multirow{3}{*}{$\begin{array}{l}\text { Candidatos } \\
\text { republicanos }\end{array}$} & Afonso Augusto Costa & 106 & 158 & 159 & 251 & 410 & 103 & 115 \\
\hline & Francisco Xavier Esteves & 107 & 159 & 159 & 250 & 409 & 104 & 112 \\
\hline & Paulo José Falcão & 106 & 158 & 158 & 253 & 411 & 103 & 113 \\
\hline \multicolumn{2}{|c|}{ Lista de entradas } & 252 & 290 & 251 & 312 & 563 & 195 & 206 \\
\hline \multicolumn{2}{|c|}{ Listas inutilizadas } & 5 & & 2 & 1 & 3 & 3 & - \\
\hline \multicolumn{2}{|c|}{ Número de cidadãos recenseados } & 447 & 424 & 422 & 476 & 898 & 362 & 380 \\
\hline
\end{tabular}

FONTE: AHP - Fundo do Tribunal de Verificação de Poderes, AEM, cx. 1989A.

Tabela 12 — Resultados Finais do Bairro Ocidental das Eleições de 26 de Novembro de 1899

\begin{tabular}{|c|c|c|c|}
\hline \multicolumn{2}{|c|}{ Candidatos } & Total & Total (\%) \\
\hline \multirow{3}{*}{$\begin{array}{c}\text { Candidatos } \\
\text { monárquicos }\end{array}$} & Abel Pereira do Vale & $\mathbf{1 6 7 2}$ & $\mathbf{1 5 . 6 7 \%}$ \\
\cline { 2 - 4 } & António Vasconcelos & $\mathbf{1 6 6 2}$ & $\mathbf{1 5 . 5 7 \%}$ \\
\cline { 2 - 4 } & Conde Campo Belo & $\mathbf{1 6 6 0}$ & $\mathbf{1 5 . 5 6 \%}$ \\
\hline \multirow{3}{*}{$\begin{array}{c}\text { Candidatos } \\
\text { republicanos }\end{array}$} & Afonso Augusto Costa & 1891 & $17.69 \%$ \\
\cline { 2 - 4 } & Francisco Xavier Esteves & 1892 & 17.74 \\
\cline { 2 - 4 } & Paulo José Falcão & 1892 & $17.74 \%$ \\
\hline
\end{tabular}

FONTE: AHP - Fundo do Tribunal de Verificação de Poderes, AEM, cx. 1989A.

Tabela 13 - Resultados das freguesias da Sé e de Santo Ildefonso nas Eleições de 25 de Novembro de 1900

\begin{tabular}{|c|c|c|c|c|c|c|c|c|c|}
\hline & & \multicolumn{4}{|c|}{ Freguesia da Sé } & \multicolumn{4}{|c|}{ Freguesia de Santo Ildefonso } \\
\hline \multicolumn{2}{|r|}{ Candidatos } & $\begin{array}{c}\text { Assembleia } \\
\text { da Sé }\end{array}$ & $\begin{array}{c}\text { Assembleia } \\
\text { do Terço }\end{array}$ & $\begin{array}{c}\text { Assembleia da } \\
\text { Misericórdia }\end{array}$ & Total & $\begin{array}{l}\text { Assembleia de } \\
\text { Santo Ildefonso }\end{array}$ & $\begin{array}{c}\text { Assembleia } \\
\text { Congregados }\end{array}$ & $\begin{array}{c}\text { Assembleia } \\
\text { Trindade }\end{array}$ & Total \\
\hline \multirow{3}{*}{$\begin{array}{l}\text { Candidatos } \\
\text { monárquicos }\end{array}$} & Clemente Pinto & 130 & 649 & 164 & 943 & 158 & 218 & 196 & 572 \\
\hline & Francisco Joaquim Fernandes & 132 & 652 & 172 & 956 & 161 & 208 & 201 & 570 \\
\hline & Souza Avides & 132 & 642 & 161 & 935 & 159 & 210 & 189 & 558 \\
\hline \multirow{3}{*}{$\begin{array}{l}\text { Candidatos } \\
\text { republicanos }\end{array}$} & Afonso Augusto Costa & 83 & 190 & 239 & 512 & 328 & 420 & 265 & 1013 \\
\hline & Francisco Xavier Esteves & 82 & 199 & 224 & 505 & 313 & 386 & 244 & 943 \\
\hline & Paulo José Falcão & 81 & 197 & 222 & 500 & 313 & 382 & 241 & 936 \\
\hline \multicolumn{2}{|c|}{ Lista de entradas } & 214 & 826 & 399 & 1439 & 486 & 613 & 447 & 1546 \\
\hline \multicolumn{2}{|c|}{ Listas inutilizadas } & & 2 & & 2 & & & & 0 \\
\hline \multicolumn{2}{|c|}{ Número de cidadãos recenseados } & 295 & 1141 & 574 & 2010 & 736 & 905 & 668 & 2309 \\
\hline \multicolumn{2}{|c|}{ Número absoluto de abstenções } & 81 & 313 & 175 & 569 & 250 & 292 & 221 & 763 \\
\hline \multicolumn{2}{|c|}{ Percentagem da abstenção } & $27.46 \%$ & $27.43 \%$ & $30.49 \%$ & $28.31 \%$ & $33.97 \%$ & $32.27 \%$ & $33.08 \%$ & $33.04 \%$ \\
\hline
\end{tabular}

FONTE: AHP - Fundo do Tribunal de Verificação de Poderes, AEM, cx. 2028. 
Tabela 14 - Resultados das freguesias de Bonfim, Campanhã e Paranhos nas Eleições de 25 de Novembro de 1900

\begin{tabular}{|c|c|c|c|c|c|c|c|c|c|}
\hline \multirow{2}{*}{\multicolumn{2}{|c|}{ Candidatos }} & \multicolumn{4}{|c|}{ Freguesia do Bonfim } & \multicolumn{3}{|c|}{ Freguesia de Campanhã } & \multirow{3}{*}{$\begin{array}{c}\begin{array}{c}\text { Freguesia de } \\
\text { Paranhos }\end{array} \\
\begin{array}{c}\text { Assembleia de } \\
\text { Paranhos }\end{array} \\
883\end{array}$} \\
\hline & & \multirow{2}{*}{$\begin{array}{c}\begin{array}{c}\text { Assembleia } \\
\text { do Bonfim }\end{array} \\
135 \\
\end{array}$} & \multirow{2}{*}{$\begin{array}{c}\begin{array}{c}\text { Assembleia } \\
\text { do Padrão }\end{array} \\
263 \\
\end{array}$} & \multirow{2}{*}{$\begin{array}{c}\begin{array}{c}\text { Assembleia } \\
\text { da Boavista }\end{array} \\
134 \\
\end{array}$} & \multirow{2}{*}{$\begin{array}{l}\text { Total } \\
532\end{array}$} & \multirow{2}{*}{$\begin{array}{c}\begin{array}{c}\text { Assembleia de } \\
\text { Campanhã }\end{array} \\
842 \\
\end{array}$} & \multirow{2}{*}{$\begin{array}{c}\begin{array}{c}\text { Assembleia de } \\
\text { São Roque }\end{array} \\
475 \\
\end{array}$} & \multirow{2}{*}{$\begin{array}{c}\text { Total } \\
1317 \\
\end{array}$} & \\
\hline & Clemente Pinto & & & & & & & & \\
\hline móńrauicos & Francisco Joaquim Fernandes & 179 & 266 & 156 & 601 & 843 & 475 & 2635 & 883 \\
\hline & $\begin{array}{l}\text { Souza Avides } \\
\end{array}$ & 136 & 263 & 134 & 533 & 839 & 475 & 1008 & 883 \\
\hline \multirow{3}{*}{$\begin{array}{l}\text { Candidatos } \\
\text { republicanos }\end{array}$} & Afonso Augusto Costa & 246 & 85 & 311 & 642 & 63 & 149 & 212 & 85 \\
\hline & Francisco Xavier Esteves & 199 & 91 & 292 & 582 & 59 & 140 & 199 & 85 \\
\hline & Paulo José Falcão & 235 & 95 & 296 & 626 & 61 & 148 & 209 & 85 \\
\hline \multicolumn{2}{|r|}{ Lista de entradas } & 383 & 361 & 446 & 1190 & 909 & 624 & 1533 & 968 \\
\hline \multicolumn{2}{|r|}{ Listas inutilizadas } & 1 & 2 & & 3 & & & $\mathbf{0}$ & \\
\hline \multicolumn{2}{|c|}{ Número de cidadãos recenseados } & 567 & 529 & 700 & 1796 & 1000 & 649 & 1649 & 1035 \\
\hline \multicolumn{2}{|c|}{ Número absoluto de abstenções } & 183 & 166 & 254 & 603 & 91 & 25 & 116 & 67 \\
\hline \multicolumn{2}{|c|}{ Percentagem da abstenção } & $32.28 \%$ & $31.38 \%$ & $36.29 \%$ & $33.57 \%$ & $9.1 \%$ & $3.85 \%$ & $7.03 \%$ & $6.47 \%$ \\
\hline
\end{tabular}

FONTE: AHP - Fundo do Tribunal de Verificação de Poderes, AEM, cx. 2028.

Tabela 15 - Resultados Finais do Bairro Oriental nas Eleições de 25 de Novembro de 1900

\begin{tabular}{|c|c|c|c|}
\hline \multirow{2}{*}{$\begin{array}{c}\text { Candidatos } \\
\text { monárquicos }\end{array}$} & Candidatos & Total & Total (\%) \\
\cline { 2 - 4 } & Clemente Pinto & 4247 & $\mathbf{2 1 . 3 0}$ \\
\cline { 2 - 4 } & Francisco Joaquim Fernandes & 4328 & $\mathbf{2 1 . 7 0}$ \\
\hline \multirow{2}{*}{$\begin{array}{c}\text { Candidatos } \\
\text { republicanos }\end{array}$} & Souza Avides & 4223 & $\mathbf{2 1 . 1 8}$ \\
\cline { 2 - 4 } & Afonso Augusto Costa & 2464 & $\mathbf{1 2 . 3 6}$ \\
\cline { 2 - 4 } & Francisco Xavier Esteves & 2314 & $\mathbf{1 1 . 6 0}$ \\
\hline
\end{tabular}

FONTE: AHP - Fundo do Tribunal de Verificação de Poderes, AEM, cx. 2028.

Tabela 16 - Resultados das freguesias de São Nicolau, Foz, Cedofeita e Ramalde nas Eleições de 25 de Novembro de 1900

\begin{tabular}{|c|c|c|c|c|c|c|c|c|}
\hline \multirow{2}{*}{\multicolumn{2}{|c|}{ Candidatos }} & \multirow{2}{*}{$\begin{array}{c}\text { Freguesia de } \\
\text { São Nicolau } \\
\text { Assembleia de } \\
\text { São Nicolau }\end{array}$} & \multirow{2}{*}{$\begin{array}{c}\text { Freguesia da Foz } \\
\text { Assembleia da Foz, } \\
\text { Aldoar e Nevogilde }\end{array}$} & \multicolumn{4}{|c|}{ Freguesia de Cedofeita } & \multirow{2}{*}{$\begin{array}{c}\begin{array}{c}\text { Freguesia de } \\
\text { Ramalde }\end{array} \\
\text { Assembleia de } \\
\text { Ramalde }\end{array}$} \\
\hline & & & & $\begin{array}{l}\text { Assembleia de } \\
\text { Carvalhido }\end{array}$ & $\begin{array}{l}\text { Assembleia de } \\
\text { Cedofeita }\end{array}$ & $\begin{array}{l}\text { Assembleia da } \\
\text { Lapa }\end{array}$ & Total & \\
\hline \multirow{3}{*}{$\begin{array}{l}\text { Candidatos } \\
\text { monárquicos }\end{array}$} & Clemente Pinto & 349 & 411 & 157 & 192 & 241 & 590 & 566 \\
\hline & Francisco Joaquim Fernandes & 354 & 419 & 175 & 195 & 238 & 608 & 573 \\
\hline & Souza Avides & 350 & 404 & 160 & 191 & 238 & 589 & 567 \\
\hline \multirow{3}{*}{$\begin{array}{l}\text { Candidatos } \\
\text { republicanos }\end{array}$} & Afonso Augusto Costa & 175 & 61 & 153 & 210 & 276 & 639 & 48 \\
\hline & Francisco Xavier Esteves & 171 & 57 & 141 & 198 & 261 & 601 & 17 \\
\hline & Paulo José Falcão & 171 & 56 & 136 & 196 & 264 & 596 & 17 \\
\hline \multicolumn{2}{|c|}{ Lista de entradas } & 526 & 480 & 316 & 396 & 509 & 1221 & 605 \\
\hline \multicolumn{2}{|c|}{ Listas inutilizadas } & & & 4 & & & 4 & \\
\hline \multicolumn{2}{|c|}{ Número de cidadãos recenseados } & 686 & 556 & 496 & 728 & 815 & 2039 & 685 \\
\hline \multicolumn{2}{|c|}{ Número absoluto de abstenções } & 160 & 76 & 176 & 332 & 306 & 814 & 80 \\
\hline \multicolumn{2}{|c|}{ Percentagem da abstenção } & $23.32 \%$ & $13.67 \%$ & $35.48 \%$ & $45.60 \%$ & $37.55 \%$ & $39.92 \%$ & $11.68 \%$ \\
\hline
\end{tabular}

FONTE: AHP - Fundo do Tribunal de Verificação de Poderes, AEM, cx. 2028

Tabela 17 - Resultados das freguesias de Massarelos, Lordelo, Vitória, Carvalhido e Miragaia nas Eleições de 25 de Novembro de 1900

\begin{tabular}{|c|c|c|c|c|c|c|c|c|}
\hline & \multirow[b]{2}{*}{ Candidatos } & \multirow{2}{*}{$\begin{array}{c}\begin{array}{c}\text { Freguesia de } \\
\text { Massarelos }\end{array} \\
\text { Assembleia } \\
\text { de Massarelos }\end{array}$} & \multirow{2}{*}{$\begin{array}{c}\begin{array}{c}\text { Freguesia de } \\
\text { Lordelo }\end{array} \\
\begin{array}{c}\text { Assembleia do } \\
\text { Lordelo }\end{array}\end{array}$} & \multicolumn{3}{|c|}{ Freguesia da Vitória } & \multirow{2}{*}{$\begin{array}{c}\begin{array}{c}\text { Freguesia do } \\
\text { Carvalhido }\end{array} \\
\text { Assembleia do } \\
\text { Carvalhido }\end{array}$} & \multirow{2}{*}{$\begin{array}{c}\begin{array}{c}\text { Freguesia de } \\
\text { Miragaia }\end{array} \\
\text { Assembleia de } \\
\text { Miragaia }\end{array}$} \\
\hline & & & & $\begin{array}{l}\text { Assembleia da } \\
\text { Vitória }\end{array}$ & $\begin{array}{l}\text { Assembleia do } \\
\text { Carmo }\end{array}$ & Total & & \\
\hline \multirow{3}{*}{$\begin{array}{l}\text { Candidatos } \\
\text { monárquicos }\end{array}$} & Clemente Pinto & 156 & 280 & 227 & 220 & 447 & 157 & 326 \\
\hline & Francisco Joaquim Fernandes & 162 & 293 & 234 & 226 & 460 & 175 & 325 \\
\hline & $\begin{array}{l}\text { Souza Avides } \\
\end{array}$ & 151 & 288 & 227 & 203 & 430 & 160 & 323 \\
\hline \multirow{3}{*}{$\begin{array}{l}\text { Candidatos } \\
\text { republicanos }\end{array}$} & Afonso Augusto Costa & 122 & 201 & 201 & 166 & 367 & 153 & 125 \\
\hline & Francisco Xavier Esteves & 104 & 189 & 181 & 157 & 338 & 141 & 111 \\
\hline & Paulo José Falcão & 108 & 185 & 181 & 154 & 335 & 136 & 110 \\
\hline \multicolumn{2}{|c|}{ Lista de entradas } & 275 & 480 & 424 & 394 & 818 & 316 & 445 \\
\hline \multicolumn{2}{|c|}{ Listas inutilizadas } & & & & 1 & 1 & 4 & \\
\hline \multicolumn{2}{|c|}{ Número de cidadãos recenseados } & 420 & 636 & 603 & 594 & 1197 & 496 & 610 \\
\hline \multicolumn{2}{|c|}{ Número absoluto de abstenções } & 145 & 156 & 179 & 199 & 378 & 176 & 165 \\
\hline \multicolumn{2}{|c|}{ Percentagem da abstenção } & $34.52 \%$ & $24.53 \%$ & $29.68 \%$ & $33.50 \%$ & $31.58 \%$ & $35.48 \%$ & $27.05 \%$ \\
\hline
\end{tabular}

FONTE: AHP - Fundo do Tribunal de Verificação de Poderes, AEM, cx. 2028. 
Tabela 18 - Resultados Finais do Bairro Ocidental nas Eleições de 25 de Novembro de 1900

\begin{tabular}{|c|c|c|c|}
\hline \multirow{4}{*}{$\begin{array}{c}\text { Candidatos } \\
\text { monárquicos }\end{array}$} & Candidatos & Total & Total (\%) \\
\cline { 2 - 4 } & Artur Eduardo Brandão & 2220 & $\mathbf{1 3 . 9 8}$ \\
\cline { 2 - 4 } & Avelino Monteiro & 2241 & $\mathbf{1 4 . 1 1}$ \\
\cline { 2 - 4 } & Francisco José Patrício & 2239 & $\mathbf{1 4 . 1 0}$ \\
\cline { 2 - 4 } & José de Cunha Lima & 2135 & $\mathbf{1 3 . 4 5}$ \\
\hline \multirow{4}{*}{$\begin{array}{c}\text { Candidatos } \\
\text { republicanos }\end{array}$} & Manoel da Sousa Avides & 2220 & $\mathbf{1 3 . 9 8}$ \\
\cline { 2 - 4 } & Afonso Augusto da Costa & 997 & $\mathbf{6 . 2 8}$ \\
\cline { 2 - 4 } & António José de Almeida & 964 & $\mathbf{6 . 0 7}$ \\
\cline { 2 - 4 } & Francisco Xavier Esteves & 957 & $\mathbf{6 . 0 3}$ \\
\cline { 2 - 4 } & Joaquim Silva Albuquerque & 950 & $\mathbf{5 . 9 8}$ \\
\cline { 2 - 4 } & Paulo José Falcão & 955 & $\mathbf{6 . 0 1}$ \\
\hline
\end{tabular}

FONTE: AHP - Fundo do Tribunal de Verificação de Poderes, AEM, cx. 2028.

Tabela 19 - Resultados Finais do Bairro Oriental nas Eleições de 6 de Outubro de 1901

\begin{tabular}{|c|c|c|c|}
\hline \multicolumn{2}{|c|}{ Candidatos } & Total & Total (\%) \\
\hline \multirow{4}{*}{$\begin{array}{c}\text { Candidatos } \\
\text { monárquicos }\end{array}$} & Clemente Joaquim Santos Pinto & 2861 & $\mathbf{1 3 . 6 1}$ \\
\cline { 2 - 4 } & Carlos Alberto Soares Cardoso & 2856 & $\mathbf{1 3 . 5 9}$ \\
\cline { 2 - 4 } & Cristóvão Magalhães Sepúlveda & 2853 & $\mathbf{1 3 . 5 7}$ \\
\cline { 2 - 4 } & António de Barbosa Mendonça & 2840 & $\mathbf{1 3 . 5 1}$ \\
\cline { 2 - 4 } & Alberto Navarro & 2904 & $\mathbf{1 3 . 8 1}$ \\
\hline \multirow{3}{*}{$\begin{array}{c}\text { Candidatos } \\
\text { republicanos }\end{array}$} & Afonso Augusto da Costa & 1352 & $\mathbf{6 . 4 3}$ \\
\cline { 2 - 4 } & António José de Almeida & 1337 & $\mathbf{6 . 3 6}$ \\
\cline { 2 - 4 } & Francisco Xavier Esteves & 1342 & $\mathbf{6 . 3 8}$ \\
\cline { 2 - 4 } & Joaquim Silva Albuquerque & 1335 & $\mathbf{6 . 3 5}$ \\
\cline { 2 - 4 } & Paulo José Falcão & 1342 & $\mathbf{6 . 3 8}$ \\
\hline
\end{tabular}

FONTE: AHP - Fundo do Tribunal de Verificação de Poderes, AEM, cx. 2063 e cx. 2064C.

Tabela 20 - Resultados Finais do Bairro Ocidental nas Eleições de 6 de Outubro de 1901

\begin{tabular}{|c|c|c|c|}
\hline \multicolumn{2}{|c|}{ Candidatos } & Total & Total (\%) \\
\hline \multirow{3}{*}{$\begin{array}{c}\text { Candidatos } \\
\text { monárquicos }\end{array}$} & Clemente Pinto & 3125 & $\mathbf{2 1 . 8 2}$ \\
\cline { 2 - 4 } & Francisco Joaquim Fernandes & 3194 & $\mathbf{2 2 . 2 3}$ \\
\cline { 2 - 4 } & Souza Avides & 3102 & $\mathbf{2 1 . 6 6}$ \\
\hline \multirow{3}{*}{$\begin{array}{c}\text { Candidatos } \\
\text { republicanos }\end{array}$} & Afonso Augusto Costa & 1738 & $\mathbf{1 2 . 1 3}$ \\
\cline { 2 - 4 } & Francisco Xavier Esteves & 1587 & $\mathbf{1 1 . 0 8}$ \\
\cline { 2 - 4 } & Paulo José Falcão & 1578 & $\mathbf{1 1 . 0 1}$ \\
\hline
\end{tabular}

FONTE: AHP - Fundo do Tribunal de Verificação de Poderes, AEM, cx. 2063 e cx. 2064C.

Imagem 1 - Fotografia do Mapa de Apuramento da Assembleia de Massarelos

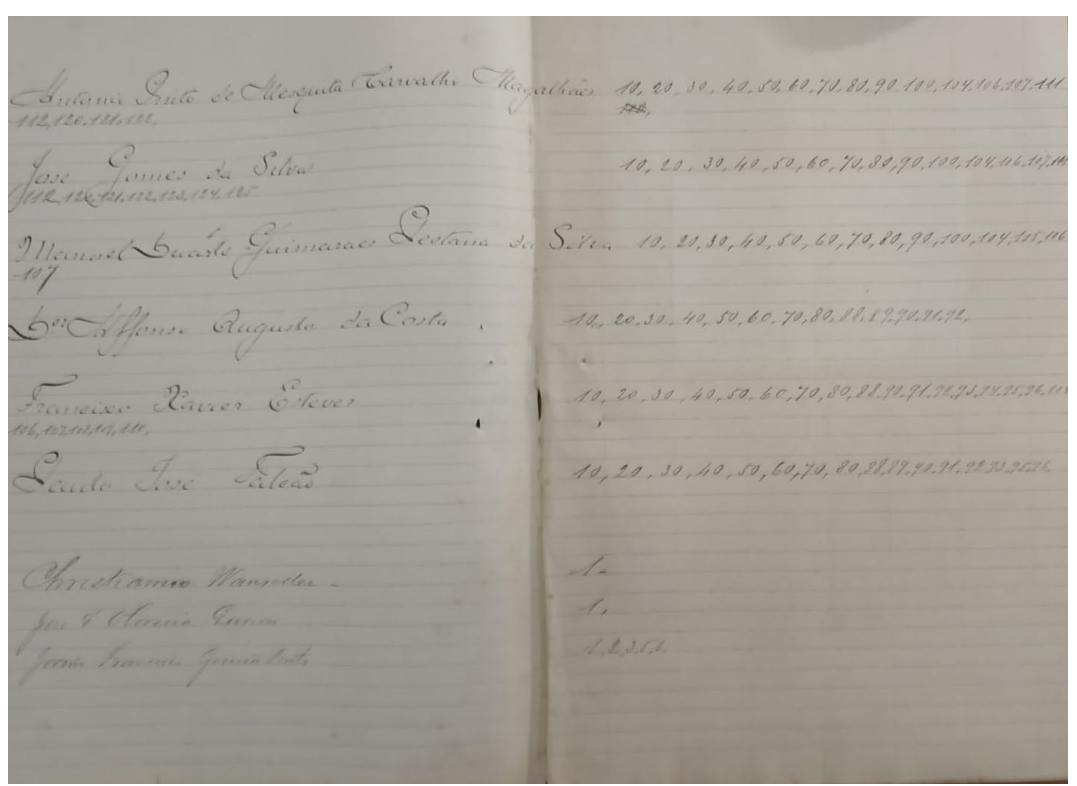

FONTE: AHP - Fundo do Tribunal de Verificação de Poderes, AEM, cx. 1637. 